\title{
MUSGOS DO PICO DA CALEDÔNEA, MUNICÍPIO DE NOVA FRIBURGO, ESTADO DO RIO DE JANEIRO, BRASIL
}

\author{
Denise Pinheiro da Costa ${ }^{1}$
}

Recebido em 5.3.92. Aceito em 30.6.94.

\begin{abstract}
RESUMO - (Musgos do Pico da Caledônea, município de Nova Friburgo, estado do Rio de Janeiro, Brasil). No Pico da Caledônea, município de Nova Friburgo, estado do Rio de Janeiro, foram encontradas 22 famílias de musgos distribuídas em 36 genêros e 53 espécies, das quais 7 espécies são citadas pela primeira vez para o Estado e 2 para o Brasil. Obra original, basiônimo, localidade-tipo, material examinado, comentários e distribuição geográfica são apresentados para cada espécie.
\end{abstract}

Palavras chave: Musgos, Nova Friburgo, Rio de Janeiro.

\begin{abstract}
Mosses of Pico da Caledônea, Nova Friburgo, Rio de Janeiro State, Brazil). Twenty two families of mosses distributed in thirty six genus and fifty three species are mentioned for the Pico da Caledônea, County of Nova Friburgo, State of Rio de Janeiro. Of these, 7 species are recorded for the first time to the state and 2 to Brazil. Bibliography, basionym, type locality, examined material, comments and geographical distribution are presented.
\end{abstract}

Key words: Mosses, Nova Friburgo, Rio de Janeiro.

\section{Introdução}

Este trabalho vem completar o levantamento das briófitas do Pico da Caledônea, situado no Município de Nova Friburgo, Estado do Rio de Janeiro, com 2020 m de altitude (Costa, 1992).

Com as alterações antrópicas, a vegetação original do pico vem sendo destruída, ficando restrita a pequenas áreas e no que diz respeito as briófitas pouco ou nada se conhece desta região.

O objetivo deste trabalho é o de contribuir para o conhecimento da brioflora do Pico da Caledônea completando o levantamento com os dados de musgos.

\footnotetext{
' Jardim Botânico do Rio de Janeiro, Rua Pacheco Leão 915, 22460-030, Rio de Janeiro-RJ, Brasil.
} 


\section{Material e métodos}

Em 1984 iniciamos uma coleção das briófitas existentes no Pico da Caledônea, com a finalidade de fazer um inventário desta brioflora. Foram realizadas 4 excursões para a área, tendo sido coletadas 104 amostras de briófitas das quais 76 são de musgos e 28 de hepáticas.

A metodologia de coleta e herborização foi baseada em Yano (1984a).

No laboratório o material foi examinado ao microscópio estereoscópico e microscópico ótico, para o exame morfológico, medidas e confecção de desenhos com o auxílio de câmara-clara. Os cortes anatômicos foram feitos à mão-livre com lâminas de barbear.

O sistema de classificação de Bryopsida adotado neste trabalho, baseia-se em Vitt (1984), com modificações propostas por Buck (1987) na Ordem Hookeriales.

Os espécimes foram identificados com o auxílio de chaves de identificação de Bartram (1928, 1949); Breen (1963); Brotherus (1909, 1924-25); Buck e Ireland (1985); Costa (1986/88); Crum (1976); Crum e Steere (1957); Eddy (1977, 1988); Enroth (1989); Farias (1982, 1984); Fife (1985); Florschütz (1964); Florschütz-de Waard (1986); Frahm (1974, 1975, 1978, 1979, 1991); Gier (1980); Griffin (1979); Grout (1903, 1945); Hyvönen (1986, 1989); Ireland \& Bellolio-Truco (1987); Kabiersh (1938); Koponen (1979, 1981, 1988); Koponen \& Norris (1983, 1984, 1985, 1986a, 1986b); Lin (1983, 1984); Magill (1987); Matteri (1975); Mello \& Yano (1991); Menzel (1986); Mitten (1869); Mullen \& Fryen (1947); Noguchi (1987, 1988); Norris \& Koponen (1985, 1988); Nyholm (1971); Ochi (1968, 1980, 1981, 1982); Sainsbury (1955); Saito (1975); Schiavone (1988a, 1988b); Schuster (198384); Sehnem (1969, 1970, 1972, 1976, 1978, 1979, 1980); Sloover (1976, 1977, 1983); Smith (1971); Tixier (1977); Touw (1975/76); Zander (1972); Welch (1966, 1976); Williams (1913); Yano (1975, 1981, 1984b, 1985, 1986, 1989); Yano \& Mello (1989); Yano et al. (1985).

Algumas amostras foram enviadas para identificação ao Dr. Dana Griffin III da Universidade da Flórida, ao Dr. William R. Buck do Jardim Botânico de Nova York e ao Dr. Jaakko Hyvönen da Universidade de Helsinki.

Toda a coleção se encontra depositada no herbário do Jardim Botânico do Rio de Janeiro (RB), com algumas duplicatas no herbário da Universidade da Flórida (FLAS).

\section{Resultados}

Sphagnaceae

Sphagnum ovatum Schimp. in Warnst., Hedwigia 29:168.1890 (fig. 1 A-F).

Localidade-tipo: não localizada

Descrição: Eddy 1977 
Material examinado - Brasil, Estado do Rio de Janeiro, Município de Nova Friburgo, Pico da Caledônea. Sobre paredão rochoso muito úmido e sombrio, próximo à nascente, a 2018 m.s.m, col. D. P. Costa 662 et al., 4-V-1988 (RB 272934).

Comentários - Esta espécie é semelhante a $S$. subsecundun Nees se diferenciando desta por apresentar curtos ramos folhosos e filídios do caulídio isoaerolados. Pode ser caracterizada por apresentar filídios do caulídio ovados ou ovado-ligulados, com margens mais ou menos curvadas, ápice arrendondado ou cuculado e células hialinas multifibrosas, não septadas. Filídios do ramo côncavos, arredondado-ovados, acuminados, com margem largamente curvada, ápice estreitamente truncado, denticulado e células clorofiladas triangulares.

Esta espécie está sendo citada pela primeira vez para o Brasil.

Sphagnum palustre L., Sp. P1. 2:1106.1753.

Localidade-tipo: Europa

Descrição e ilustração: Yano et al. 1985.

Material examinado - Brasil, Estado do Rio de Janeiro, Município de Nova Friburgo, Pico da Caledônea. Sobre o solo, na mata perenifólia, protegido pela vegetação herbácea, no alto do pico, 2020 m.s.m, col. D. P. Costa 238 et al., 2-VII-1988 (RB 259602).

Comentários - A espécie apresenta polimorfismo sendo considerada um "complexo taxonômico".

É uma espécie cosmopolita e ocorre no Brasil nos Estados de Roraima, Amazonas, Pará, Ceará, Paraíba, Pernambuco, Sergipe, Minas Gerais, Espírito Santo, Rio de Janeiro, São Paulo, Paraná, Santa Catarina, Rio Grande do Sul (Yano 1981).

Sphagnum recurvum P. Beauv., Prodr. 88. 1805.

Localidade-tipo: não localizada

Descrição e ilustração: Yano et al. 1985.

Material examinado - Brasil, Estado do Rio de Janeiro, Município de Nova Friburgo, estrada para as torres de televisão, Rio Caledônea, reserva da EMASA. Sobre pedra da cascata, alt. 1550 m.s.m., col. G. L. Ferreira 173 et al., 11-VIII-1987 (RB 263389).

Comentários - Esta espécie pode ser reconhecida pela cor verde-clara ou amarelada dos gametófitos e pelos filídios dos ramos falcados, com ápice patente.

É uma espécie cosmopolita e no Brasil ocorre nos Estados de Mato Grosso, Minas Gerais, Espírito Santo, Rio de Janeiro, São Paulo, Paraná, Santa Catarina, Rio Grande do Sul. 
Sphagnum subsecundum Nees., Deustch. Fl. Crypt. 2(17):3.1819, sensu lato.

Localidade-tipo: não indicada

Descrição e ilustração: Yano et al. 1985.

Material examinado - Brasil, Estado do Rio de Janeiro, Município de Nova Friburgo, Pico da Caledônea. Sobre paredão rochoso úmido e sombrio, próximo à nascente no alto do pico, alt. 2020 m.s.m., col. D. P. Costa 643 et al., 4-V-1988 (RB 272936).

Comentários - Esta espécie apresenta polimorfismo, mas pode ser reconhecida pelo arranjo em fileiras dos pequenos e numerosos poros anelados na margem dos leucocistos dos filídios do ramo (Yano et al. 1985).

É uma espécie com distribuição cosmopolita e no Brasil ocorre nos Estados de Roraima, Amazonas, Bahia, Goiás, Mato Grosso, Espírito Santo, Rio de Janeiro, São Paulo, Paraná, Santa Catarina, Rio Grande do Sul (Yano 1981).

Polytrichaceae

Atrichum androgynum var. oerstedianum (C. Müll.) Nyholm, Lindbergia 1:26:1971. (Fig. 2 A-F).

Basiônimo: Catharinea oerstediana C. Müll., Syn 2:558.1851.

Localidade-tipo: Costa Rica.

Descrição: Nyholm 1971.

Material examinado - Brasil, Estado do Rio de Janeiro, Município de Nova Friburgo, Pico da Caledônea. Caminho para o pico, na margem da estrada, local exposto, col. D. P. Costa 71, 31-VIII-1984 (RB 249100).

Comentários - Esta espécie pode ser reconhecida por apresentar gametófito robusto; filídios com base larga e ápice truncado, serreados do meio até a base; dentes duplos na margem; células da base retangulares e as do ápice quadráticas ou irregulares; lamelas formadas por 1-3 células, costa curto-percurrente.

Ocorre nos Estados de Minas Gerais, Rio de Janeiro, Santa Catarina, Rio Grande do Sul (Farias 1984; Yano 1981, 1989).

Pogonatum campylocarpum (C. Müll.) Mitt., J. Linn. Soc. Bot. 12:618.1869. (Fig. 3 A-D).

Basiônimo: Polytrichum campylocarpum C. Müll., Syn. Musc. Frond 1:209.1848.

Localidade-tipo: Venezuela, Caracas, Galipan.

Descrição: Menzel 1986.

Material examinado - Brasil, Estado do Rio de Janeiro, Munícipio de Nova Friburgo, Morro da Caledônea. Crescendo na encosta úmida, com folhas verdes, alt. 1400-1600 m.s.m.; col. G. Martinelli 2460 et al., 8-VI-1977 (RB 257237). 


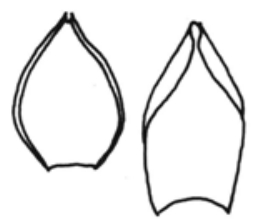

A
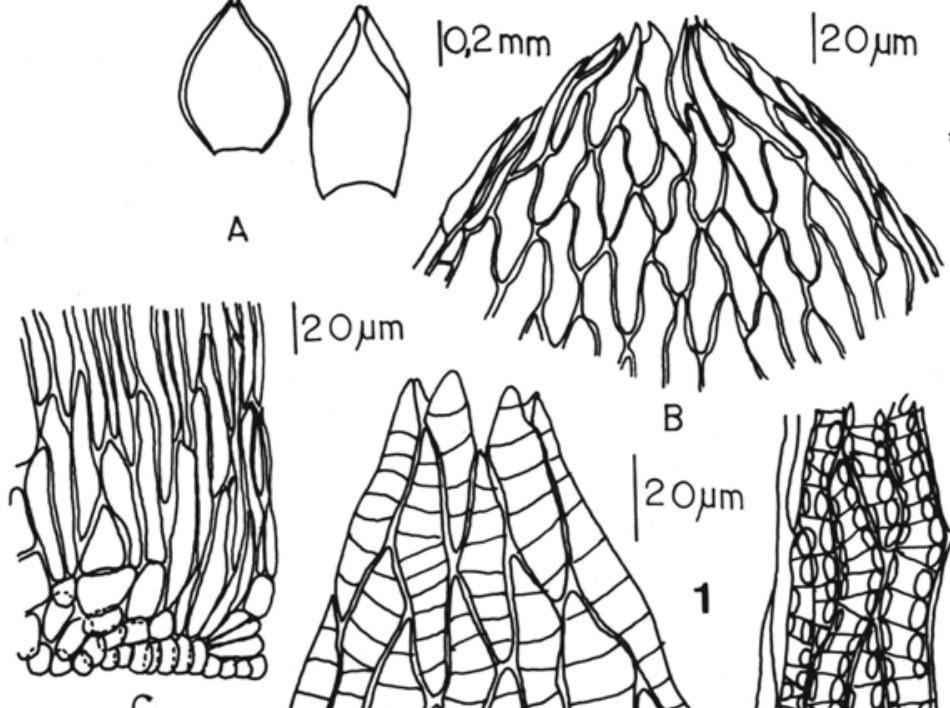

$120 \mu \mathrm{m}$
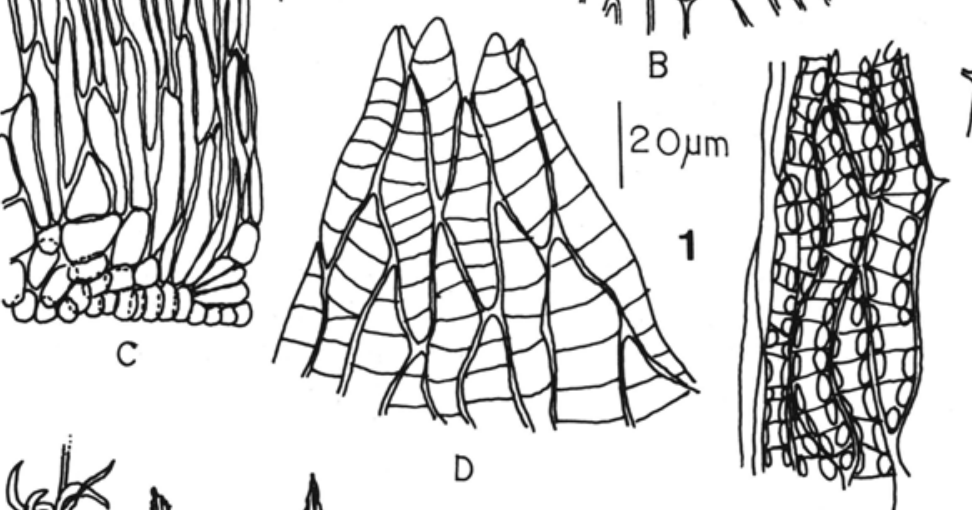

D
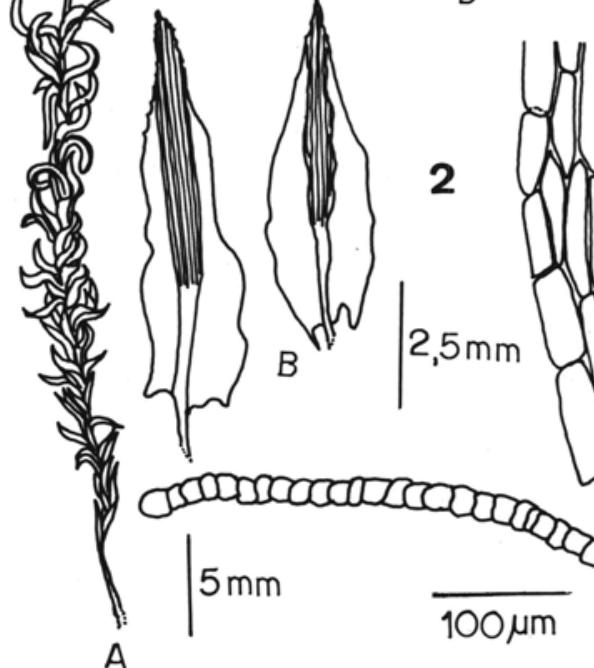

E
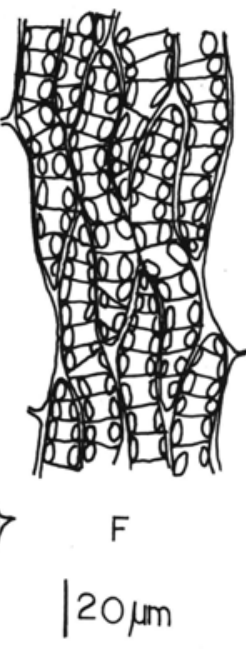
Comentários - Esta espécie pode ser reconhecida por apresentar filídios com bainha estreitada, margem serrada, plicada e arqueada; células apicais papilosas; cápsula curta.

Ocorre nos Estados de Minas Gerais, Rio de Janeiro, (Yano 1981, 1989).

Polytrichadelphus magellanicus (Hedw.) Mitt., J. Linn. Soc. Bot. 4:97.1859. (Fig. 4 A-H).

Localidade-tipo: Fuegia, Magellan.

Descrição: Schiavone 1988a, b.

Material examinado - Brasil, Estado do Rio de Janeiro, Município de Nova Friburgo, Morro da Caledônea, Umbrófila, rupícola, $9 \mathrm{~cm}$ de altura, folhas filiformes, verde brilhantes, alt. 1400-1600 m.s.m., col G. Martinelli 2530 et al., 8-VI-1977 (RB 193214).

Comentários - Esta espécie pode ser reconhecida por apresentar gametófitos robustos; filídios com base larga, oblongo ou ovado, repentinamente lanceolado-subulado com ápice pontudo, costa formando uma arista denteada de coloração vermelha; lamelas formadas por 5-8 fileiras de células, sendo a célula terminal alargada e ovada.

Ocorre no Estado de Minas Gerais, Rio de Janeiro, Santa Catarina (Yano 1981).

Polytrichum commune Hedw., Spec. Musc. 88.1801. (Fig. 5 A-C).

Localidade-tipo: "Vulgaris per todam European".

Descrição: Farias 1982.

Material examinado - Brasil, Estado do Rio de Janeiro, Município de Nova Friburgo, Pico da Caledônea. Sobre o solo humoso, junto com líquens, protegido pela vegetação arbustiva do alto do pico, muito úmido, alt. 2018 m.s.m. D. P. Costa 651, 4-V-1988 (RB 272938).

Comentários - Esta espécie pode ser reconhecida por apresentar caulídio ereto, decumbente; filídios em corte transversal com lamelas formadas por 4-9 células sendo as terminais largas, constrictas no meio ou mais raramente divididas em 2 células.

Ocorre nos Estados de Minas Gerais, Rio de Janeiro, São Paulo, Paraná, Santa Catarina, Rio Grande do Sul (Yano 1981, 1989).

Polytrichum juniperinum Hedw., Spec. Musc. 89.1801 (Fig. 6 A-D).

Localidade-tipo: Suíça.

Descrição: Farias 1982.

Material examinado - Brasil, Estado do Rio de Janeiro, Município de Nova Friburgo, Morro da Caledônea. Rupícola, umbrófila, $7 \mathrm{~cm}$ de altura, folhas filiformes, verdeclaras, fértil, 1400-1600 m.s.m., col. G. Martinelli 2516, 8-VI-1977 (RB 196373); 


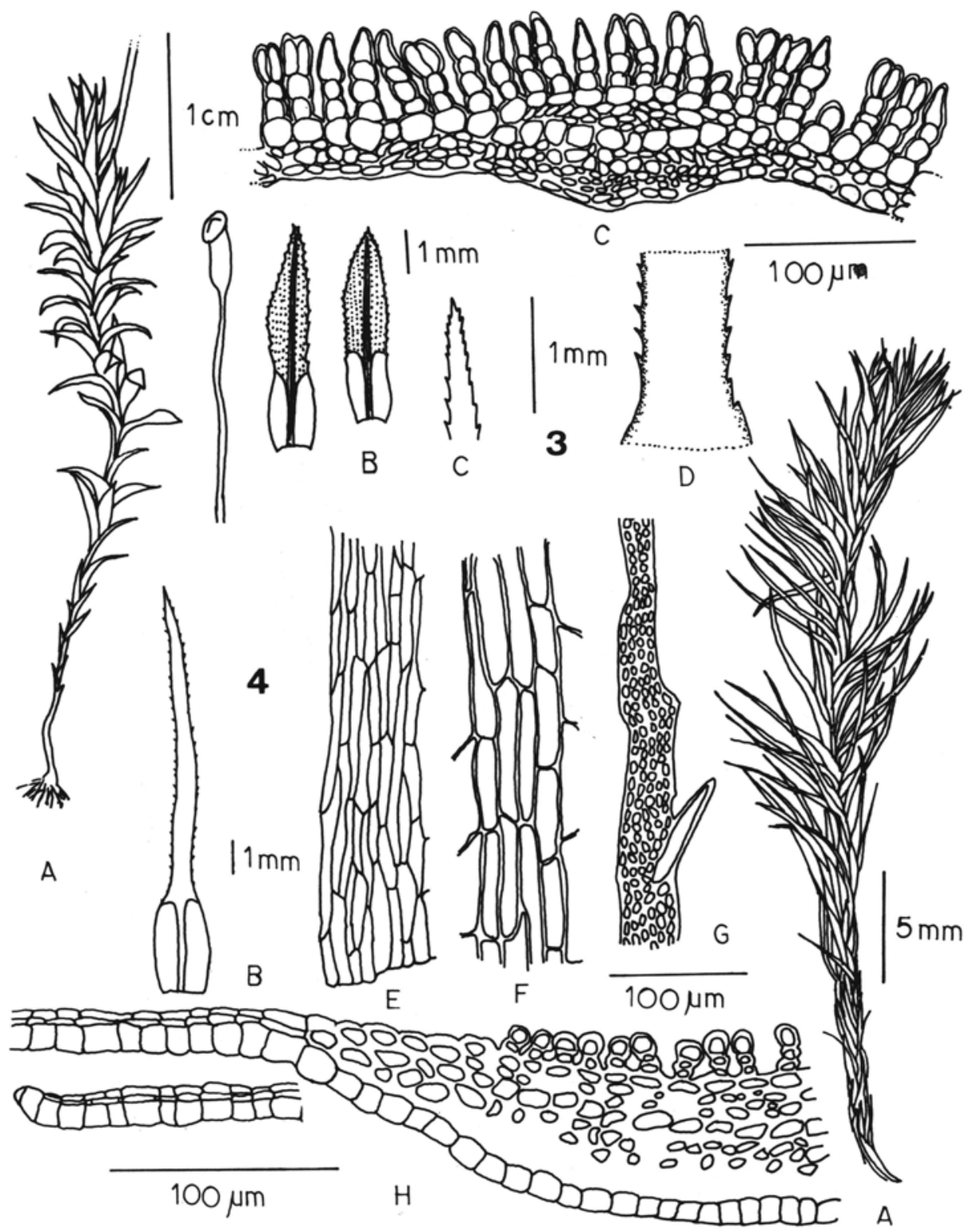

Figura 3. Pogonatum campylocarpum A) Gametófito; B) Filídios; C) Corte transversal do filídio. Figura 4. Polytrichadelphus magellanicus A) Gametófito; B) Filídio; C-D) Detalhe do ápice e da região mediana da costa; E) Células basais do filídio; F) Células da região mediana; G) Células marginais do filídio; H) Corte transversal do filídio. 


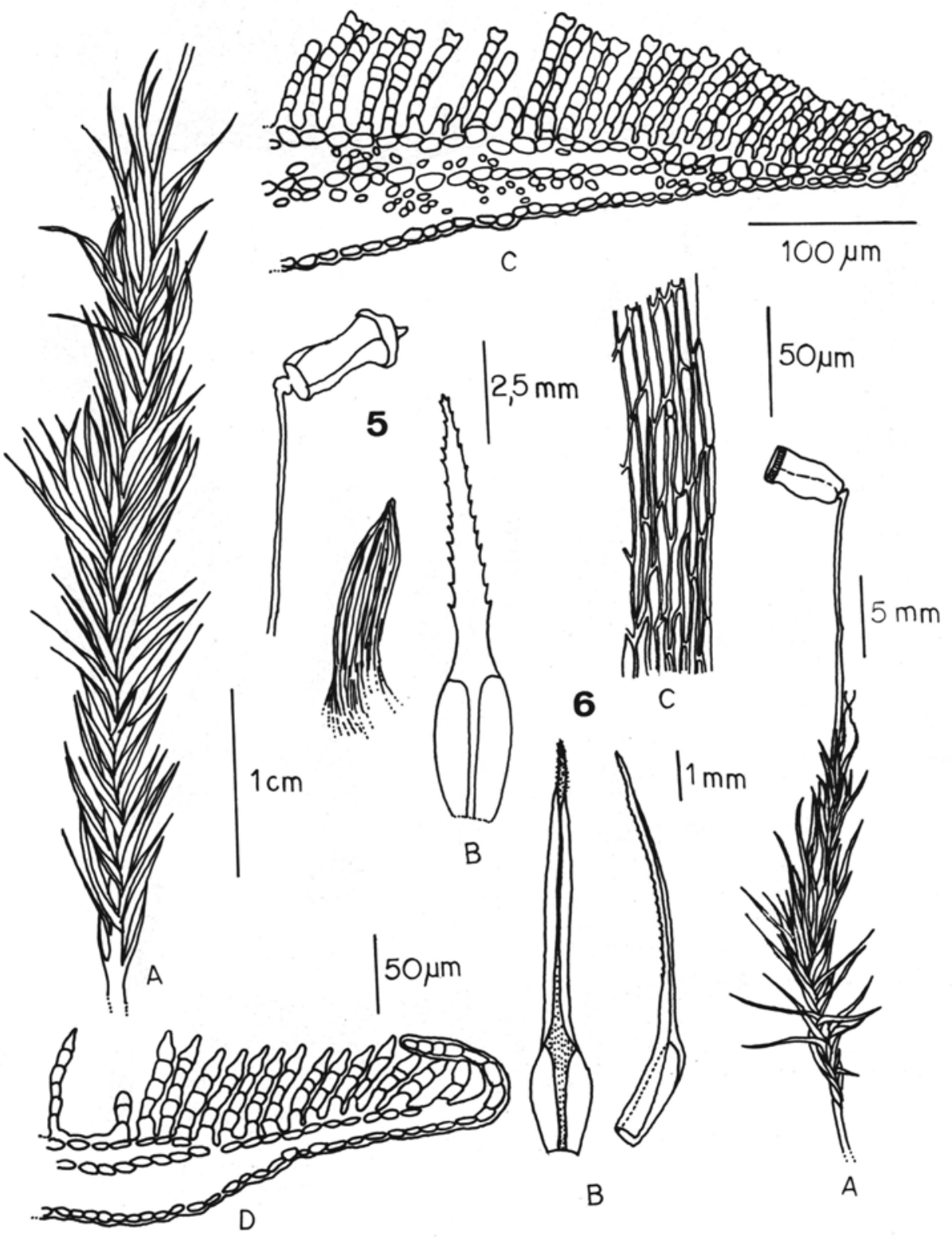

Figura 5. Polytrichum commune A) Gametófito com esporófito, cápsula e caliptra; B) Filídio; C) Corte transversal do filídio. Figura 6. Polytrichum juniperinum A) Gametófito; B) Filídios; C) Células marginais do filídio; D) Corte transversal do filídio. 
ibidem. Ereto, rupícola, crescendo sobre a encosta úmida, umbrófila, alt. 1400-1600 m.s.m., idem 2540, 8-VI- 1977 (RB 200497); ibidem. Barranco de terra exposto na beira da estrada, este margeia todo o caminho até o alto do pico, col. D. P. Costa 66, 31-VIII-1984 (RB 230528); ibidem. Em barranco à beira da estrada, heliofila, alt. 1800 m.s.m., idem 241 et L. C. Giordano, 2-VI-1987 (RB 259605); ibidem. Ocorrendo sobre rochas, folhas verdes, haste marrom e caliptra de verde a pardo, col. R. Guedes 2082 et al., 16/17-VI-1987 (RB 260920); ibidem. Musgo, alt. 1600-1410 m, col. A. M. F. Vaz 164, 8-VI-1977 (RB 271575).

Comentários - Esta espécie pode ser reconhecida por apresentar gametófitos gregários; caulídio anguloso; filídios lanceolados com ápice avermelhado, denticulado, aristado; margem dobrada acima dos "ombros"; em corte transversal o filídio apresenta lamelas com 6-7 fileiras de células, sendo a terminal alargada na base, estreita e arredondada no ápice.

Esta espécie apresenta distribuição cosmopolita e no Brasil ocorre nos Estados da Bahia, Minas Gerais, Rio de Janeiro, São Paulo, Paraná, Santa Catarina, Rio Grande do Sul (Yano 1981, 1989).

\section{Funariaceae}

Funaria hygrometrica Hedw., Spec. Musc. 172.1801 (Fig. 7 A-G). Localidade-tipo: Alemanha.

Descrição: Fife 1985.

Material examinado - Brasil, Estado do Rio de Janeiro, Município de Nova Friburgo, Pico da Caledônea. Entre pedras à beira do caminho, protegido pela cobertura herbácea, alt. 2000 m.s.m., col. D. P. Costa 228 et L. C. Giordano, 2-VI-1987 (RB 259592); ibidem. Entre as pedras do caminho (rupícola e heliófila), alt. 1830 m.s.m., idem 239 et L. C. Giordano, 2-VI-1987 (RB 259603).

Comentários - Esta espécie pode ser reconhecida por apresentar filídios contorcidos quando secos, oblongo-ovados, côncavos, curto-acuminados, inteiros ou fracamente denteados; costa sub-percurrente; seta longa, flexuosa; cápsula piriforme, assimétrica, sulcada, peristômio com dentes espiraladamente curvados, unidos no ápice por um disco.

É uma espécie cosmopolita, comum em locais perturbados e ocorre no Brasil nos Estados do Pará, Pernambuco, Mato Grosso, Rio de Janeiro, Paraná, Santa Catarina, Rio Grande do Sul (Yano 1981, 1989).

Orthotrichaceae

Schlotheimia rugifolia (Hook.) Schwaegr., Spec. Musc. Suppl. 2(1):150.1824.

Basiônimo: Orthotrichum rugifolium Hook., Musc. Exot. 128.1820. 

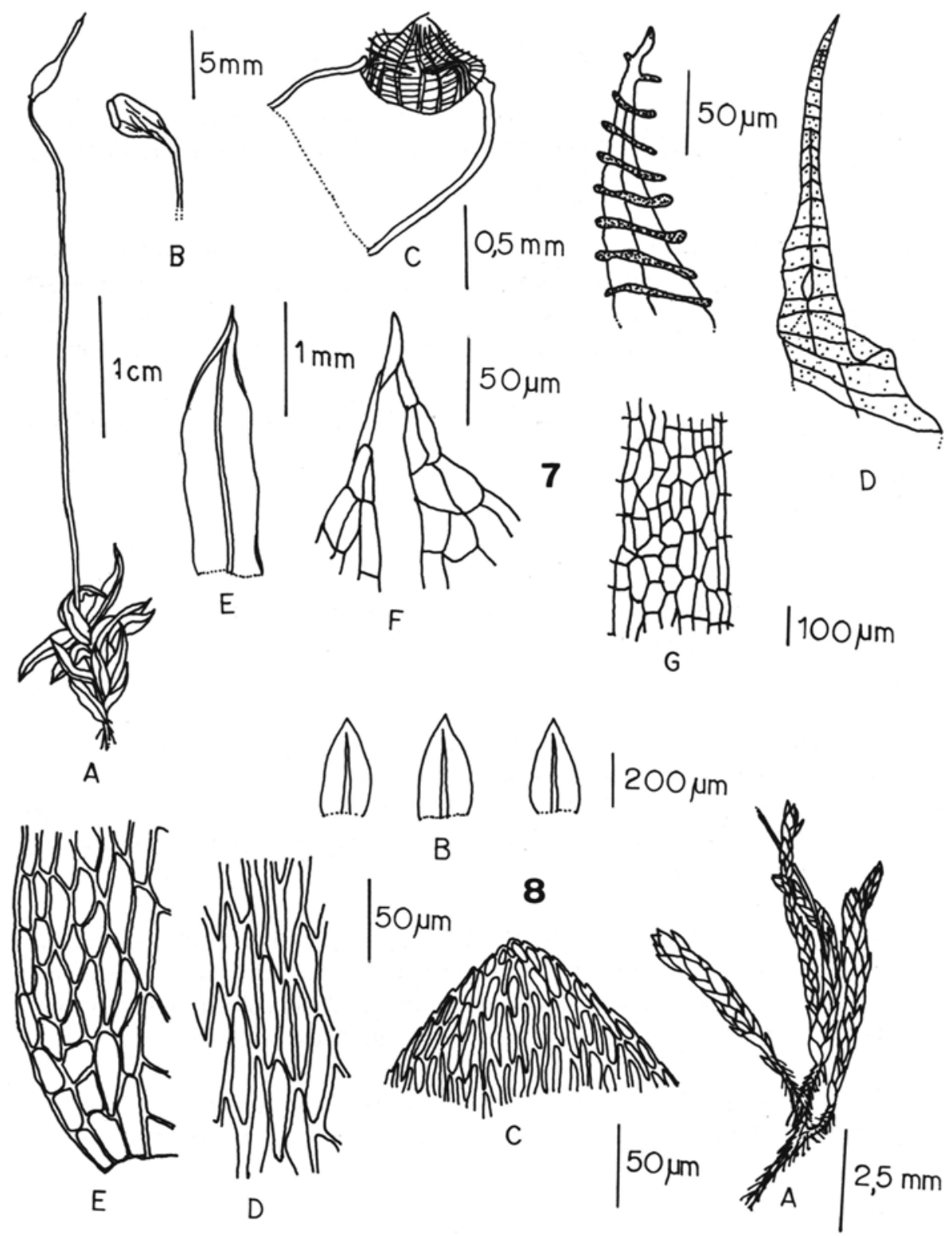

Figura 7. Funaria hygrometrica A) Gametófito; B-C) Cápsula; D) Dentes do exóstoma e endóstoma; E) Filídio; F) Ápice do filídio; G) Células medianas do filídio. Figura 8.Anomobryum filiforme A) Gametófito; B) Filídios; C) Células do ápice do filídio; D) Células medianas do filídio; E) Células basais do filídio. 
Localidade-tipo: Sebastianpolin, Swainson.

Descrição e ilustração: Mello \& Yano 1991.

Material examinado - Brasil, Estado do Rio de Janeiro, Município de Nova Friburgo. caminho para o Pico da Caledônea. Sobre pedra na beira da estrada exposta, col. D. P. Costa 69, 31-VIII-1984 (RB 230529).

Comentários - Esta espécie pode ser reconhecida por apresentar gametófitos com filídios espiralados quando secos, ligulados, curto-mucronados, rugosos no ápice, com costa forte, curto-excurrente; células lisas, sendo as apicais pequenas e redondas enquanto que as basais são lineares e sinuosas.

Ocorre nos Estados do Amazonas, Pernambuco, Bahia, Goiás, Mato Grosso, Minas Gerais, Rio de Janeiro, São Paulo, Paraná, Santa Catarina, Rio Grande do Sul (Yano 1981, 1989).

Bryaceae

Anomobryum filiforme (Dicks.) Husn., Musc. Gall. 222.1888. (Fig. 8 A-E).

Basiônimo: Bryum filiforme Dicks., Pl. Crypt. fasc. 4:16.1801.

Localidade-tipo: Escócia.

Descrição: Ochi 1980, 1981, 1982.

Material examinado - Brasil, Estado do Rio de Janeiro, Município de Nova Friburgo, Pico da Caledônea. Rupícola, heliófila, alt. 2000 m.s.m., col. D. P. Costa 231 et al., 2VII-1987. (RB 259595).

Comentários - Esta espécie pode ser reconhecida por apresentar caulídios juláceos, com filídios imbricados, costa sub-percurrente; células apicais do filídio lineares e longas, com paredes espessadas; seta longa, delgada e flexuosa; cápsula com pescoço distinto; segmentos do endóstoma com uma membrana basal alta, divididos e com cílios.

Ocorre apenas no Estado de Minas Gerais (Yano 1981), sendo citada pela primeira vez para o Estado do Rio de Janeiro.

Bryum argentum Hedw., Spec. Musc. 181.1801 (Fig. 9 A-D).

Localidade-tipo: Europa.

Descrição: Ochi 1980, 1981, 1982.

Material examinado - Brasil, Estado do Rio de Janeiro, Município de Nova Friburgo, Pico da Caledônea. Terreno rochoso, sobre o solo humoso, heliófila, alt. 2000 m.s.m., col. D. P. Costa 223 et al., 2-VI-1987 (RB 259588); ibidem. Entre as pedras da estrada, local exposto, idem 236 et al., 2-VI-1987 (RB 259600). 

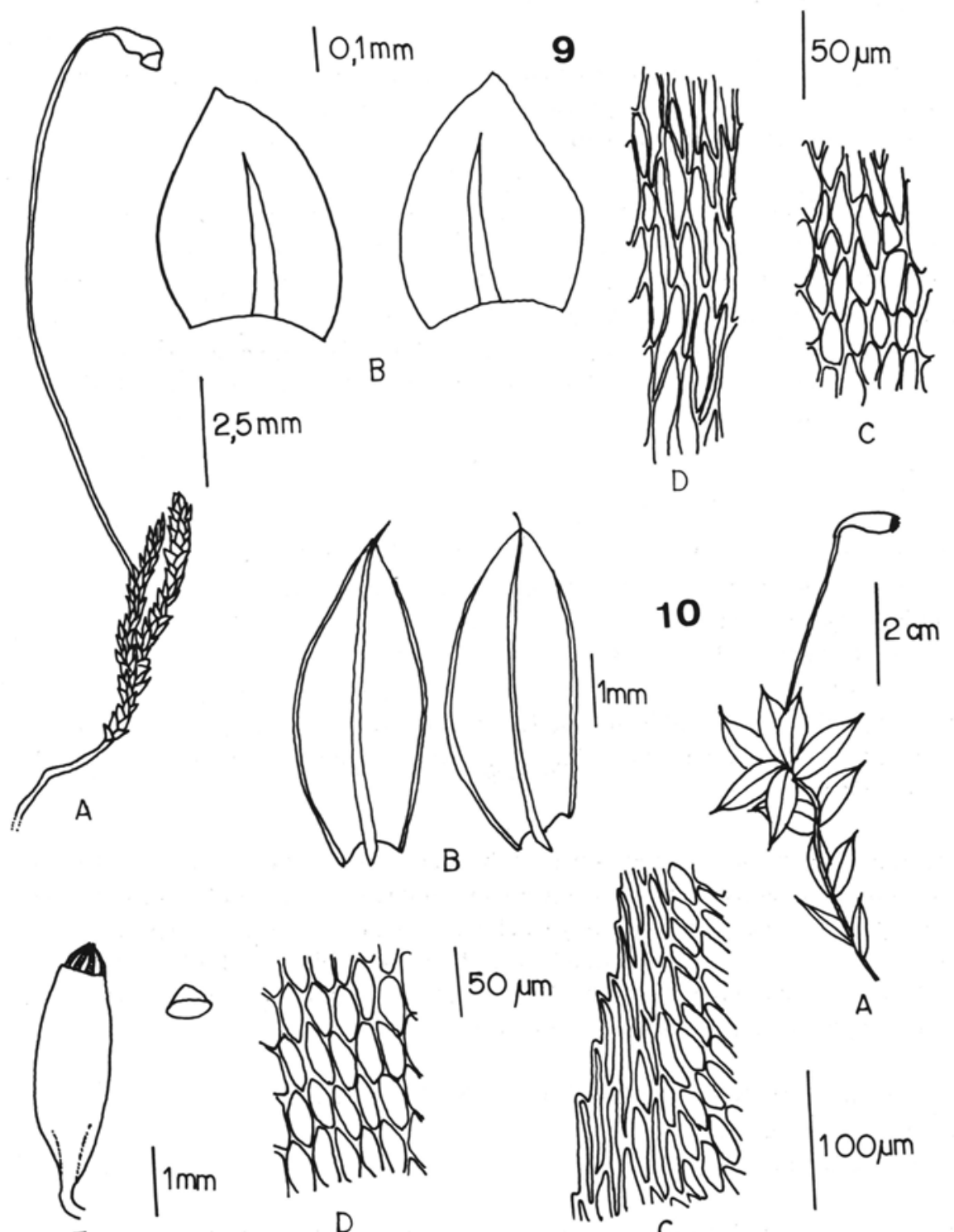

E
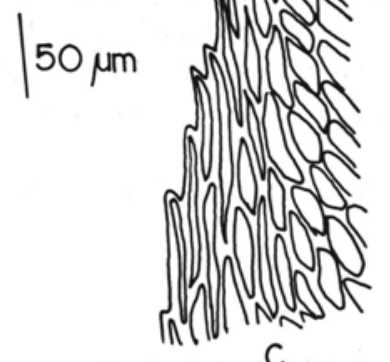

A

C

Figura 9. Bryum argenteum A) Gametófito; B) Filídios; C) Células basais do filídio; D) Células apicais do filídio. Figura 10. Bryum billarderi A) Gametófito; B) Filídios; C) Margem do filídio; D) Células medianas do filídio; E) Cápsula e opérculo. 
filídios, os quais são compactos; cápsulas pêndulas de coloração rosada ou vermelha.

É uma espécie cosmopolita e no Brasil ocorre nos Estados do Amazonas, Pernambuco, Goiás, Mato Grosso, Rio de Janeiro, São Paulo, Santa Catarina (Yano 1981).

Bryum billarderi Schwaegr., Spec. Musc. Suppl. 1(2):115.76.1816. (Fig. 10 A-E). Localidade-tipo: Austrália.

Descrição: Koponen \& Norris 1984.

Material examinado - Brasil, Estado do Rio de Janeiro, Município de Nova Friburgo, Pico da Caledônea. No solo humoso da mata de altitude, protegido pela vegetação herbácea, col. D. P. Costa 650 et al., 4-V-1988 (RB 277994).

Comentários - Esta espécie pode ser reconhecida por apresentar planta de tamanho variável, geralmente grande, filídios superiores maiores que os inferiores, formando uma roseta; filídios obovados, com ápice agudo, margem recurvada com 2-6 fileiras de células lineares, serreada; costa excurrente formando uma robusta ponta serreada; células alongadas, regularmente hexagonal, com paredes mais ou menos espessadas.

Ocorre nos Estados de Rondônia, Goiás, Mato Grosso, Minas Gerais, Rio de Janeiro, São Paulo, Santa Catarina (Yano 1989).

Bryum roseolum C. Müll., Linnaea 42:287.1879. (Fig. 11 A-F).

Localidade-tipo: Argentina.

Descrição: Ochi 1980, 1981, 1982.

Material examinado - Brasil, Estado do Rio de Janeiro, Município de Nova Friburgo, Pico da Caledônea. Sobre pedra do riacho no caminho para o pico, muito úmida e sombria, alt. 1600 m.s.m., col. D. P. Costa 888 et al., 30-III-1989 (RB 283864).

Comentários - Esta espécie pode ser reconhecida por apresentar gametófitos muito robustos com até $10 \mathrm{~cm}$ de comprimento; filídios obovado-oblongos com ápices acuminados e estreitos na base; margem revoluta na base, na região mediana plana, denticulada para o ápice, bordeada por células estreitas, longas e lineares, dentes grandes como espinhos; seta longa, cápsula arqueada-clavada, horizontal ou inclinada; peristômio com segmentos perfurados e longos cílios no endóstoma.

Ocorre nos Estados da Bahia, Rio de Janeiro, Rio Grande do Sul (Yano 1989).

Plagiomniaceae

Plagiomnium rhynchophorum (Hook.) T. Kop., Hikobia 6:57.1972. (Fig. 12 A-F).

Basiônimo: Mnium rhynchophorum Hook., Icon. Pl. Par. 1, tab20. fig. 3.1836.

Localidade-tipo: Nepal.

Descrição: Koponen 1981. 


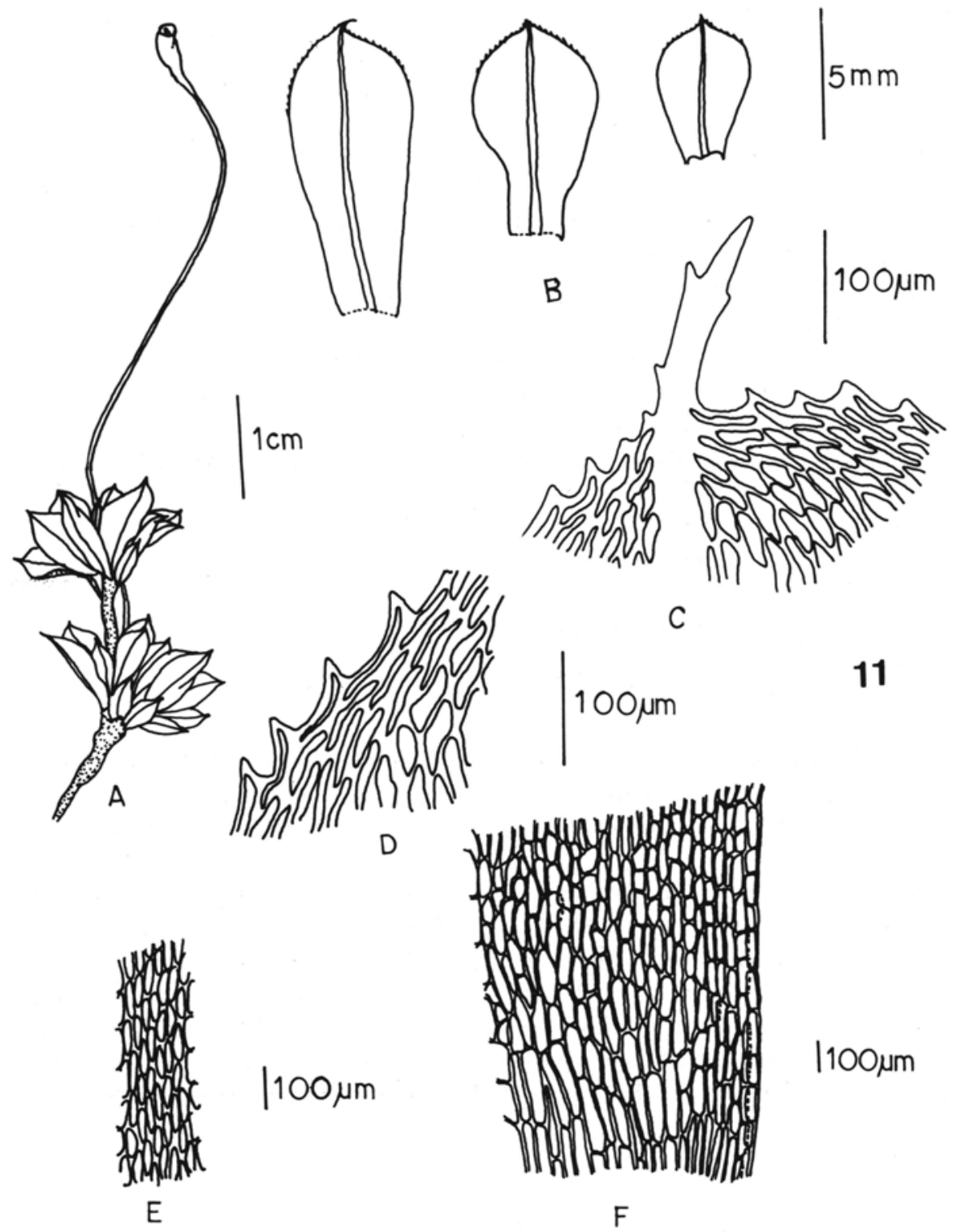

Figura 11. Bryum roseolum A) Gametófitos; B) Filídios; C) Ápice do filídio; D) Margem do filídio; E) Células medianas do filídio; F) Células basais do filídio. 


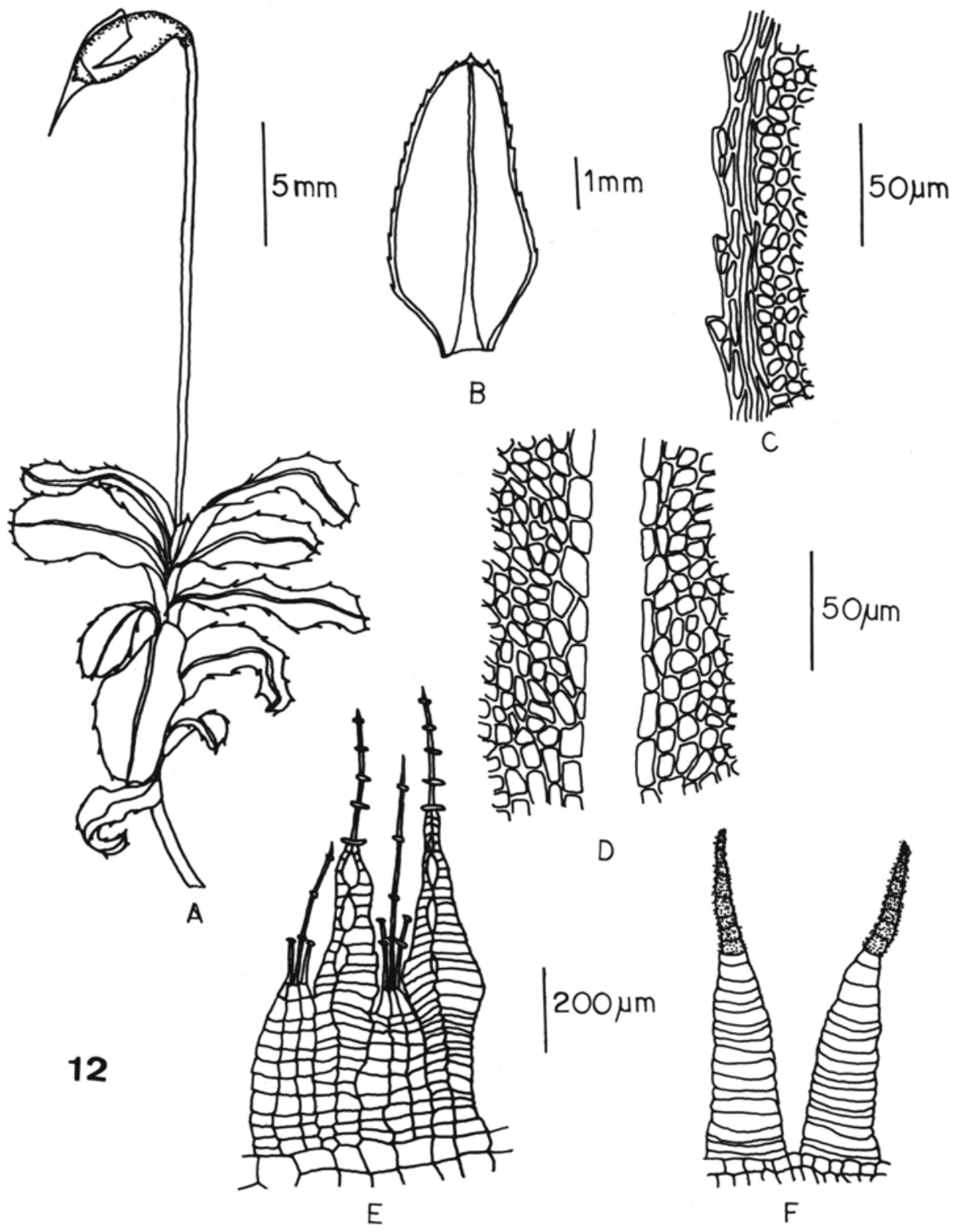

Figura 12. Plagiomnium rhynchophorum A) Gametófito; B) Filídio; C) Margem do filídio; D) Células do filídio próximas da costa; E) Endóstoma; F) Exóstoma. 
Material examinado - Brasil, Estado do Rio de Janeiro, Município de Nova Friburgo, caminho para o Pico da Caledônea. Antes do rio, col. D. P. Costa 88, 9-IX-1984 (RB 230531); ibidem. Sobre pedra à beira do rio, heliófila, alt. 1150 m.s.m., idem 227 et L. C. Giordano, 2-VI-1987 (RB 259591).

Comentários - Esta espécie pode ser reconhecida por apresentar gametófitos de coloração verde ou verde-amarelado, caulídio radiculoso na base; filídios em rosetas. largos, elípticos-oblongos; ápices redondos ou retusos, curto-apiculados; margens planas, bordeadas, denticuladas ou não; células redondo-hexagonais, lisas.

Ocorre nos Estados de Minas Gerais, Rio de Janeiro, São Paulo, Santa Catarina, Rio Grande do Sul (Yano 1981, 1989).

Mniaceae

Pyrrhobryum spiniforme (Hedw.) Mitt., J. Linn. Soc. Bot. 10:174.1869.

Basiônimo: Hypnum spiniforme Hedw., Sp. Musc. 236.1801.

Localidade-tipo: Jamaica.

Descrição e ilustração: Yano 1986.

Material examinado - Brasil, Estado do Rio de Janeiro, Município de Nova Friburgo, Pico da Caledônea. Rupícula, ciófila, folhas verdes, col. G. Martinelli 4426, 9-V-1978 (RB 210556).

Comentários - Esta espécie pode ser reconhencida por apresentar gametófitos de coloração castanho-avermelhados e esporófitos com setas longas que nascem na base do caulídio; filídios linear-lanceolados, acuminados, margem espessa, espinhososerreada; dentes aos pares; costa forte, denteada; células arrendondadas. Geralmente encontrada fértil.

Ocorre nos Estados de Roraima, Amazonas, Pernambuco, Bahia, Minas Gerais, Espírito Santo, Rio de Janeiro, São Paulo, Paraná, Santa Catarina, Rio Grande do Sul (Yano 1981, 1989).

Bartramiaceae

Philonotis glaucescens (Hornsch.) Par., Ind. Bryol. 923.1814. (fig. 13 A-D).

Basiônimo: Bartramia glaucescens Hornsch., Fl. Brasil. 1:40.1840.

Localidade-tipo: Brasil.

Descrição: Sehnem 1976.

Material examinado - Brasil, Estado do Rio de Janeiro, Município de Nova Friburgo, Pico da Caledônea. Rupícola, em local muito úmido, por onde escorria água, semiheliófila, alt. 1950 m.s.m., col. D. P. Costa 229 et L. C. Giordano, 2-VI-1987 (RB 


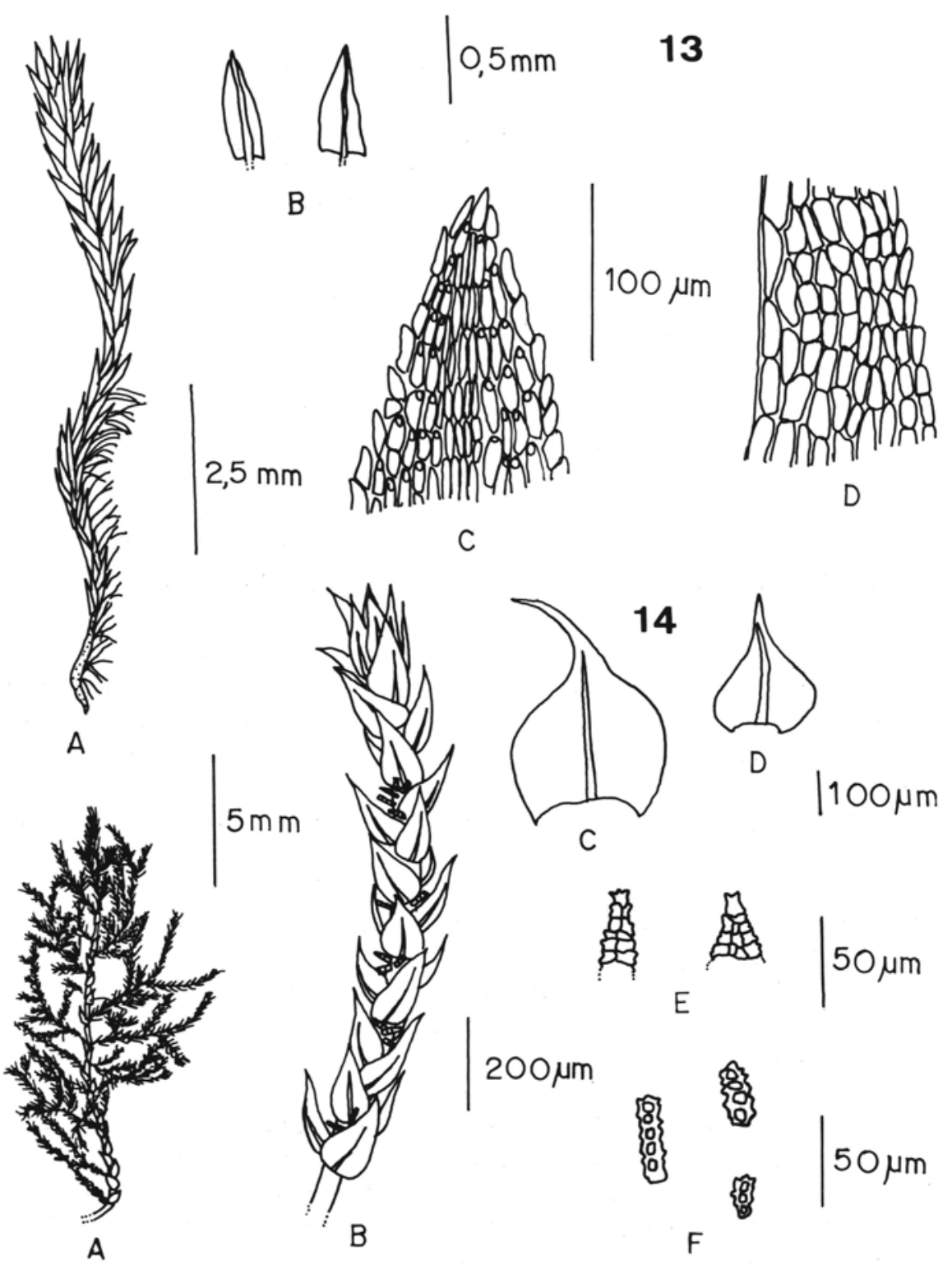

Figura 13. Philonotis glaucescens A) Gametófito; B) Filídios; C) Ápice do filídio; D) Células medianas do filídio. Figura 14. Cyrtohypnum minutulum A) Gametófito; B) Detalhe do ramo; C) Filídio do caudílio; D) Filídio do ramo; E) Ápice do filídio; F) Parafilias. 
259593); ibidem, caminho para o Pico da Caledônea, sobre pedra da cascata por onde escorria água, alt. 1800 m.s.m., idem 653 et al., 4-V-1988 (RB 284177).

Comentários - Esta espécie pode ser reconhecida por apresentar gametófitos pequenos, filídios imbricados, subfalcados, lanceolados, acuminados; costa percurrente; margem recurvada; células lineares-oblongas, papilosas nos ângulos superiores.

Ocorre nos Estados do Amazonas, Mato Grosso, Minas Gerais, Rio de Janeiro, São Paulo, Paraná, Santa Catarina, Rio Grande do Sul (Yano 1981, 1989).

Thuidiaceae

Cyrtohypnum minutulum (Hedw.) Buck \& Crum, Contr. Univ. Mich. Herb. 17:66.1990. (fig. 14 A-F).

Basiônimo: Hypnum minutulum Hedw., Spec. Musc. 260.1801.

Localidade-tipo: Jamaica e Cuba.

Descrição: Bartram 1949.

Material examinado - Brasil, Estado do Rio de Janeiro, Municipio de Nova Friburgo, Pico da Caledônea. Em pedra na beira do rio, col. D. P. Costa 85, 8-IX-1984 (RB 259593).

Comentários - Esta espécie pode ser reconhecida por apresentar gametófitos pequenos, com ramificação irregular, pinada ou bipinada; com pouca ou muita parafilia; filídio ovado-lanceolado, acuminado, côncavo; costa subpercurrente; células hexagonais, papilosas.

Ocorre nos Estados de Minas Gerais, São Paulo (Yano 1981, 1989), sendo citada pela primeira vez para o Rio de Janeiro.

Thuidium recognitum (Hedw.) Lindb. var. delicatulum (Hedw.) Warnst., Bot. Centralbl. 5:185. 1881 (fig. 15 A-E).

Basiônimo: Hypnum delicatulum Hedw., Spec. Musc. 260.1801.

Localidade-tipo: Pensilvania

Descrição: Bartram 1949.

Material examinado - Brasil, Estado do Rio de Janeiro, Município de Nova Friburgo, Pico da Caledônea. Crescendo na encosta, umbrófila, em lugar bastante úmido, alt. 1400-1600 m.s.m., col. G. Martinelli 2438, 8-VI-1977 (RB 257236); ibidem. Estrada para torres de televisão, Rio Caledônea, Reserva da EMASA. Em árvore, col. G. L. Ferreira 176 et al., 11-VIII-1987 (RB 263465); ibidem. Sobre tronco em decomposição no chão da mata úmida e fechada, alt. 2018 m.s.m., col. D. P. Costa 666, 4-V-1988 (RB 272931).

Comentários - Esta espécie pode ser reconhecida por apresentar gametófitos robustos, 

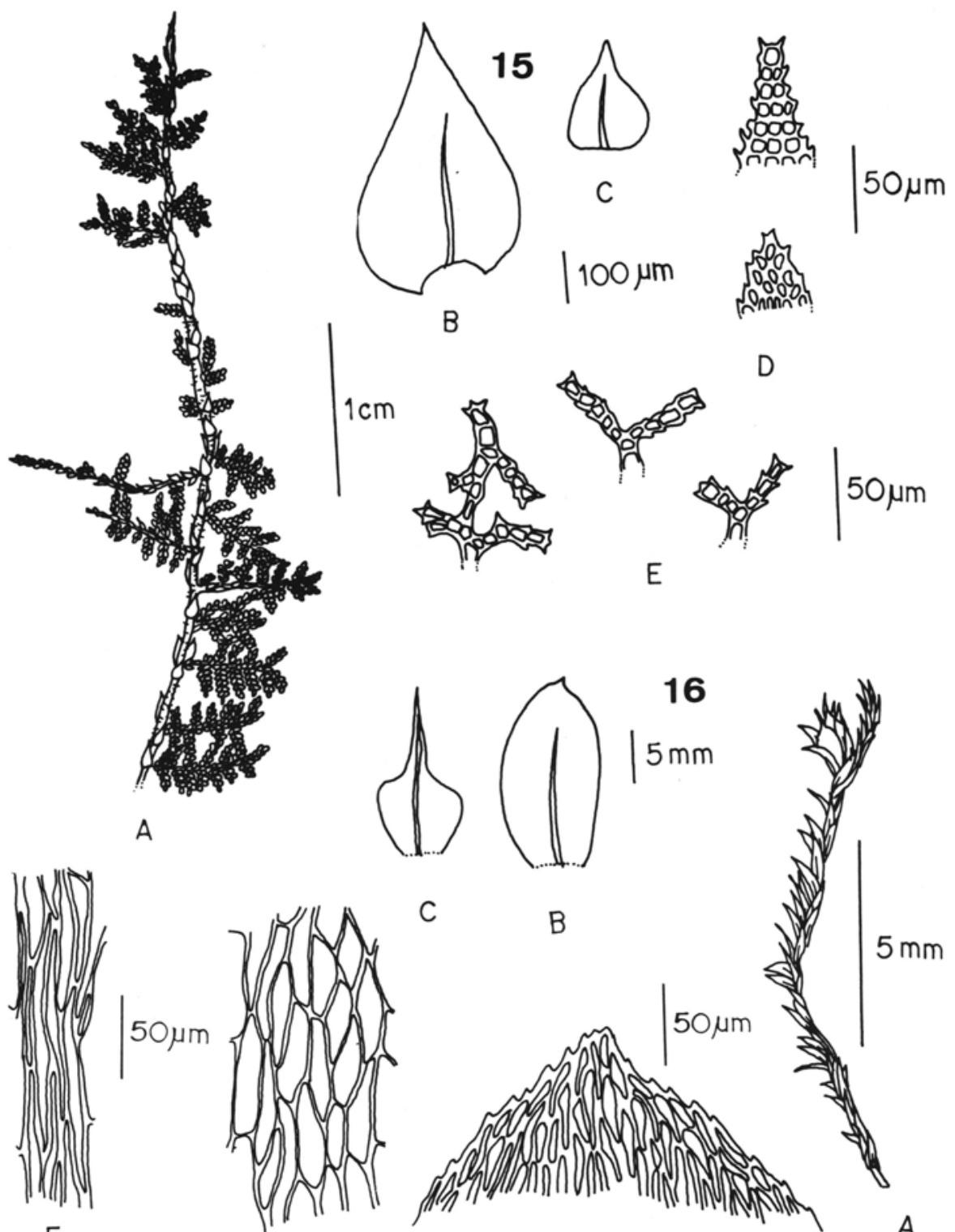

$E$
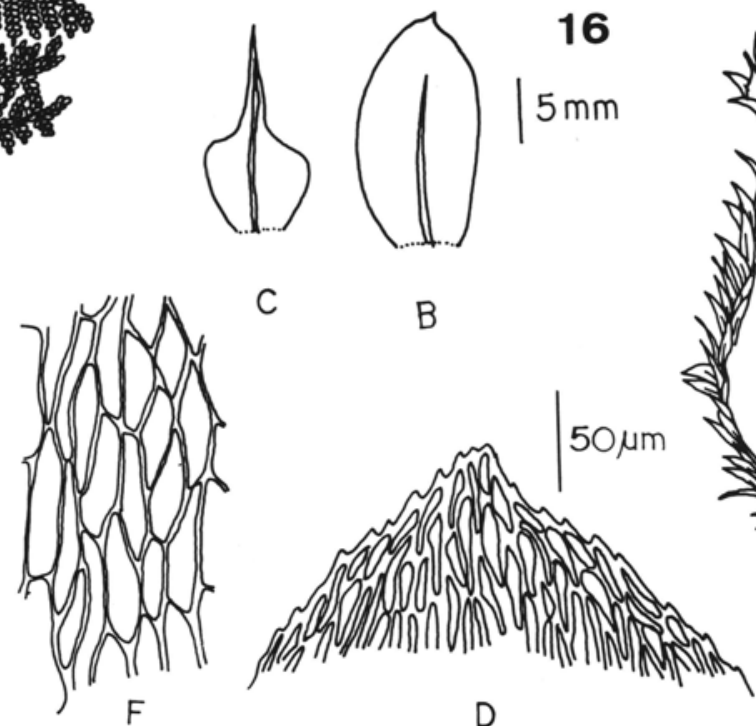

$5 \mathrm{~mm}$

Figura 15.Thuidium recognitum var. delicatulum A) Gametófito; B) Filídio do caulídio; C) Filídio do ramo; D) Ápice do filídio; E) Parafílias. Figura 16. Stereophyllum radiculosum A) Gametófito; B) Filídios; C) Filídios periqueciais: D) Células apicais do filídio; E) Células medianas do filídio; F) Células basais do filídio. 
com ramificacão bipinada ou tripinada; parafília abuntante; filídios triangular-ovados com base subcordada, sulcados, acuminados; costa percurrente; células curto-oblongas, papilosas; filídios dos ramos menores, ovados, côncavos, curto-acuminados: células curtas com uma papila sobre o lúmem.

Ocorre nos Estados do Amazonas, Rio de Janeiro (Yano 1981, 1989).

Stereophyllaceae

Stereophyllum radiculosum (Hook.) Mitt., J. Linn. Soc. Bot. 12:542.1869. (fig. 16 AF).

Basiônimo: Hookeria radiculosa Hook., Musci Exot. 1:51.1818.

Localidade-tipo: Crepidines juxta Caripe, locis scopulosis, temperatis, irriguis, altitudine 480 hexapod, Humboldt et Bompland (Isótipo NY).

Descrição: Buck \& Ireland 1985.

Material examinado - Brasil, Estado do Rio de Janeiro, Município de Nova Friburgo, Pico da Caledônea. Entre as pedras da estrada, local exposto (rupícola e heliófila), alt. 1830 m.s.m., col. D. P. Costa 235 et L. C. Giordano, 2-VI-1987 (RB 259599).

Comentários - Esta espécie pode ser reconhecida por apresentar células curtas, romboidais, geralmente unipapilosas, com papilas sobre lúmem; costa curta.

É um gênero monotípico e no Brasil ocorre nos Estados de Minas Gerais, Rio de Janeiro, São Paulo, Paraná (Yano 1981, 1989).

Hypnaceae

Mittenothamnium heterostachys (Hampe) Card., Revue Bryol. Lichénol. 40:21.1913. (fig. 17 A-E).

Basiônimo: Hypnum heterostachys Hampe, Medd. Naturh. For. Kjoebenh. ser. 3,6:169.1875.

Localidade-tipo: Brasil.

Descrição: Sehnem 1979.

Material examinado - Brasil, Estado de Rio de Janeiro, Município de Nova Friburgo, estrada para torres de televisão, Rio Caledônea, Reserva da EMASA. Sobre árvore no caminho paralelo ao rio, col. G. L. Ferreira 175 et al., 11-VIII-1987 (RB 265397).

Comentários - Esta espécie pode ser reconhecida por apresentar gametófitos com muitos ramos densamente folhosos; filídios da estipe ereto-patentes, estreitos, lancolados, acuminados, fracamente serreados nos ápices; costa dupla e curta; células estreitas, sendo as alares um pouco mais laxas; filídios periqueciais longamente subulados.

Ocorre nos Estados de Minas Gerais, Rio de Janeiro, São Paulo, Rio Grande do Sul (Yano 1981, 1989). 


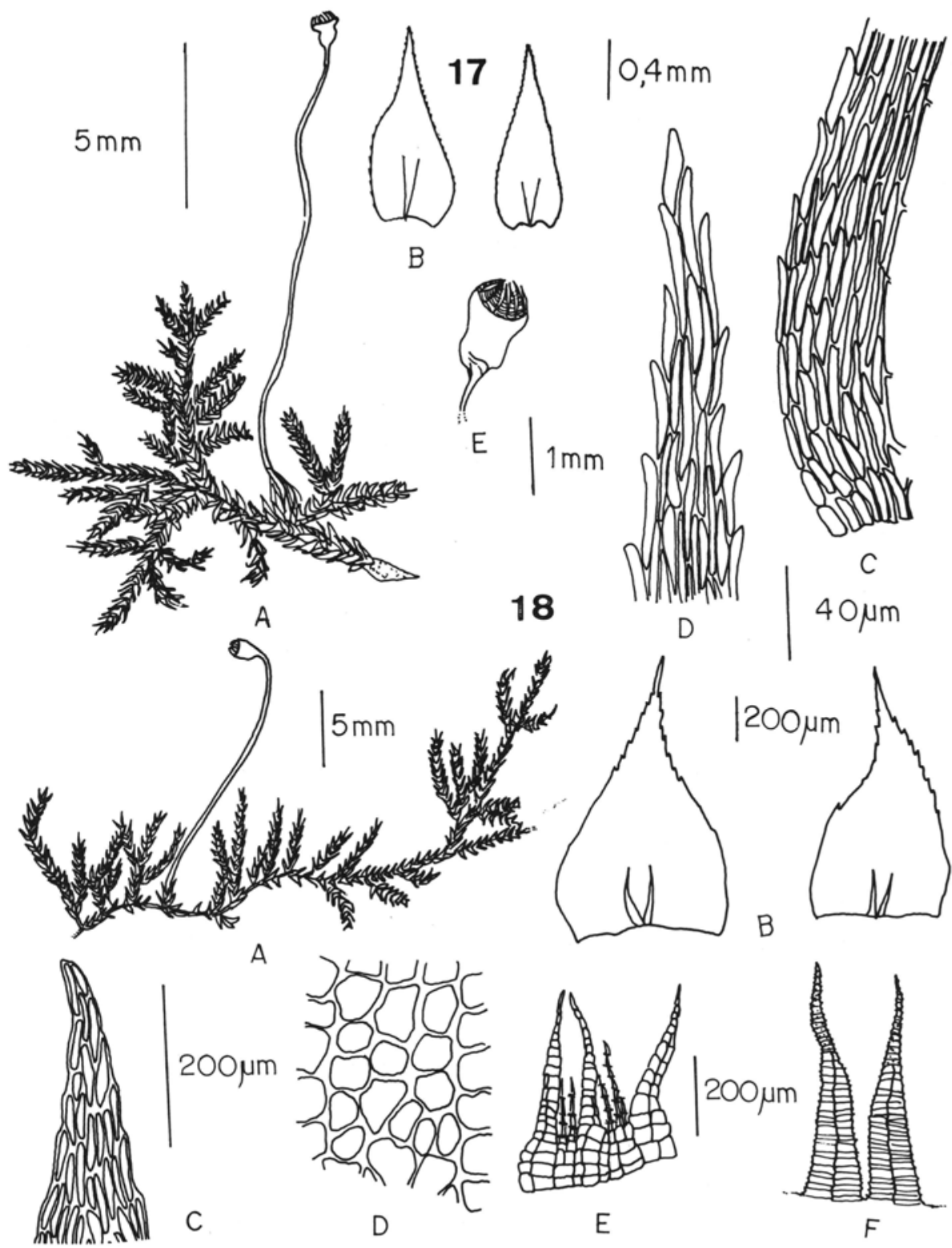

Figura 17. Mittenothamnium heterostachys A) Gametófito; B) Filídios; C) Células basais do filídio; D) Células apicais do filídio; E) Cápsula. Figura 18. Mittenothamnium langsdorfii A) Gametófitos; B) Filídios; C) Células apicais do filídio; D) Células da parede da cápsula; E) Endóstoma; F) Exóstoma. 
Mittenothamnium langsdorfii (Hook.) Card., Revue Bryol. Lichénol. 40:21.1913. (fig. 18 A-F).

Basiônimo: Hypnum langsdorfii Hook., Kunth. Pl. Aequim. 1:62.1822-28.

Localidade-tipo: Jamaica et insulae meridionales.

Descrição: Bartram 1949.

Material examinado - Brasil, Estado do Rio de Janeiro, Município de Nova Friburgo, estrada para as torres de televisão, Rio Caledônea, Reserva da EMASA. Sobre pedra, col. G. L. Ferreira 171 et al., 11-VIII-1987 (RB 265400).

Comentários - Esta espécie pode ser reconhecida por apresentar gametófitos com caulídio primário rastejante e secundário ereto, irregularmente ramificados e estipitados; filídios com base subauriculada, ápice acuminado; costa curta, dupla ou ausente; células curto-lineares, sendo as da base laxas e oblongas.

Ocorre nos Estados do Pará, Ceará, Minas Gerais, Rio de Janeiro, São Paulo, Paraná, Santa Catarina (Yano 1981, 1989).

Mittenothamnium reptans (Hedw.) Card., Revue Bryol. Lichénol. 40:21.1913. (fig. 19 A-D).

Basiônimo: Hypnum reptans Hedw., Spec. Musc. 265.1801.

Localidade-tipo: Jamaica et insulae meridionales.

Descrição: Bartram 1949.

Material examinado - Brasil, Estado do Rio de Janeiro, Município de Nova Friburgo, estrada para as torres de televisão, Rio Caledônea, Reserva da EMASA. Em árvore misturado com Porotrichum substriatum (Hampe) Mitt. e Lindigia aciculata (Tayl.) Hampe, col. G. L. Ferreira 178 et al., 11-VIII-1987 (RB 265398).

Comentários - Esta espécie pode ser reconhecida por apresentar gametófitos com caulídios arqueados, radiculosos no ápice, livremente ramificado, estipitado; filídios da estipe distantes, acuminados, com base larga, cordada, ligeiramente decurrente; costa dupla e curta; células lineares; filídios dos ramos complanados, ovado-lanceolados, fortemente serrulados.

Ocorre nos Estados de Minas Gerais, Rio de Janeiro, São Paulo, Paraná, Santa Catarina, Rio Grande do Sul (Yano 1981, 1989).

Sematophyllaceae

Aptychella proligera (Broth.) Herz., Biblioth. Bot. 87:157-76.1916.(fig. 20 A-D)

Basiônimo: Rhapidostegium proligerum (Dus.) Broth., Naturl. Pflanzenfam. 1,3:782.1908.

Localidade-tipo: México.

Descrição: Tixier 1977. 


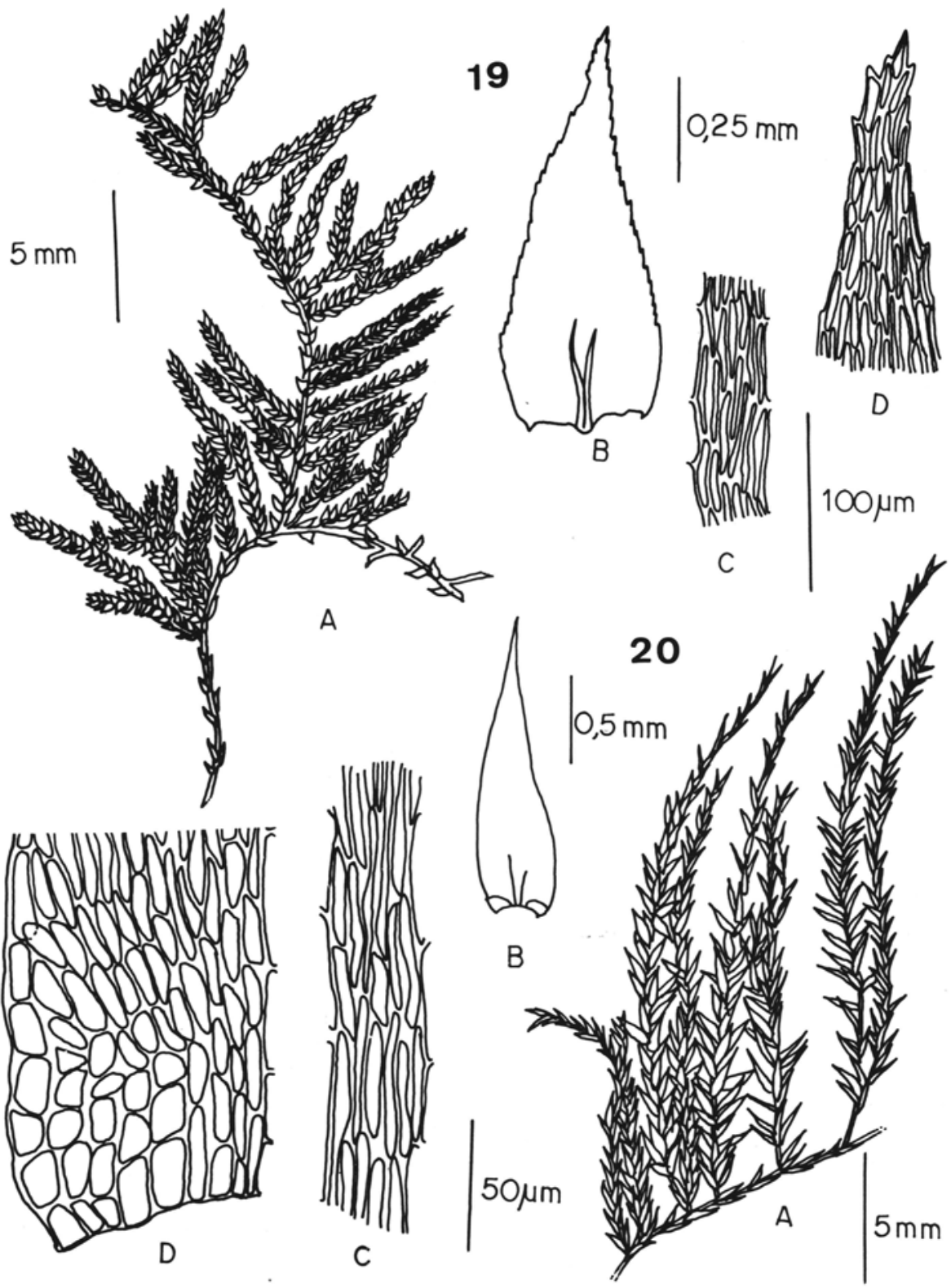

Figura 19. Mittenothamnium reptans A) Gametófito; B) Filídio; C) Células medianas do filídio; D) Células apicais do filídio. Figura 20. Aptychella proligera A) Gametófito; B) Filídios; C) Células medianas do filídio; D) Células basais do filídio. 
Material examinado - Brasil, Estado do Rio de Janeiro, Município de Nova Friburgo, Pico da Caledônea. Sobre tronco em decomposição no chão da mata sombria e úmida, alt. 2018 m.s.m., col. D. P. Costa 652 et al., 4-V-1988 (RB 272928).

Comentários - Esta espécie pode ser reconhecida por apresentar caulídios filamentosos; filídios triangulares, mais ou menos côncavos, ápice flageliforme, margem no ápice discretamente crenulada, base auriculada, com costa dupla e desigual.

Esta espécie apresenta distribuição tropical e está sendo citada pela primeira vez para o Brasil.

Sematophyllum caespitosum (Hedw.) Mitt., J. Linn. Soc. Bot. 12:479.1869.

Basiônimo: Leskea caespitosa (Hedw.), Spec. Musc. 233. t.49f. 1-5.1801.

Localidade-tipo: Insula Hispaniola.

Descrição e ilustração: Mello \& Yano 1991.

Material examinado - Brasil, Estado do Rio de Janeiro, Município de Nova Friburgo, caminho para o Pico da Caledônea. No rio, em pedra submersa, col. D. P. Costa s/no. 9-IX-1984 (RB 265177).

Comentários - Esta espécie pode ser reconhecida por apresentar células oval-romboidais, curtas no ápice e mais alongadas abaixo, células alares oblongas, pouco infladas em grupo de 3-4, as supras alares subquadráticas.

Ocorre nos Estados do Amazonas, Pará, Pernambuco, Goiás, Mato Grosso, Minas Gerais, Rio de Janeiro, São Paulo, Paraná, Santa Catarina, Rio Grande do Sul (Yano 1981, 1989).

Sematophyllum campicola (Broth.) Broth., Naturl. Pflanzenfam. ed. 2,11:432.1925. (Fig. 21 A-E).

Basiônimo: Rhaphidostegium campicola Broth., Bih. K. Svensk. Vet. Ak. Foerh. 21. Afd. 3(3):53.1895.

Localidade-tipo: Brasil, Minas Gerais.

Descrição: Sehnem 1978.

Material examinado - Brasil, Estado do Rio de Janeiro, Município de Nova Friburgo, estrada para as torres de televisão, Rio Caledônea, Reserva da EMASA. Na pedra do rio, col. G. L. Ferreira 172 et al., 11-VIII-1987 (RB 267114).

Comentários - Esta espécie pode ser reconhecida por apresentar gametófitos brilhantes, com ramos curtos, filídios sem costa, ovados, obtusos; com células alares infladas, longas, quadráticas ou retangulares; filídios periqueciais oblongos-acuminados; seta com 6-8mm.

Ocorre nos Estados de Minas Gerais, Paraná e está sendo citada pela primeira vez para o Estado do Rio de Janeiro (Yano 1981, 1989). 


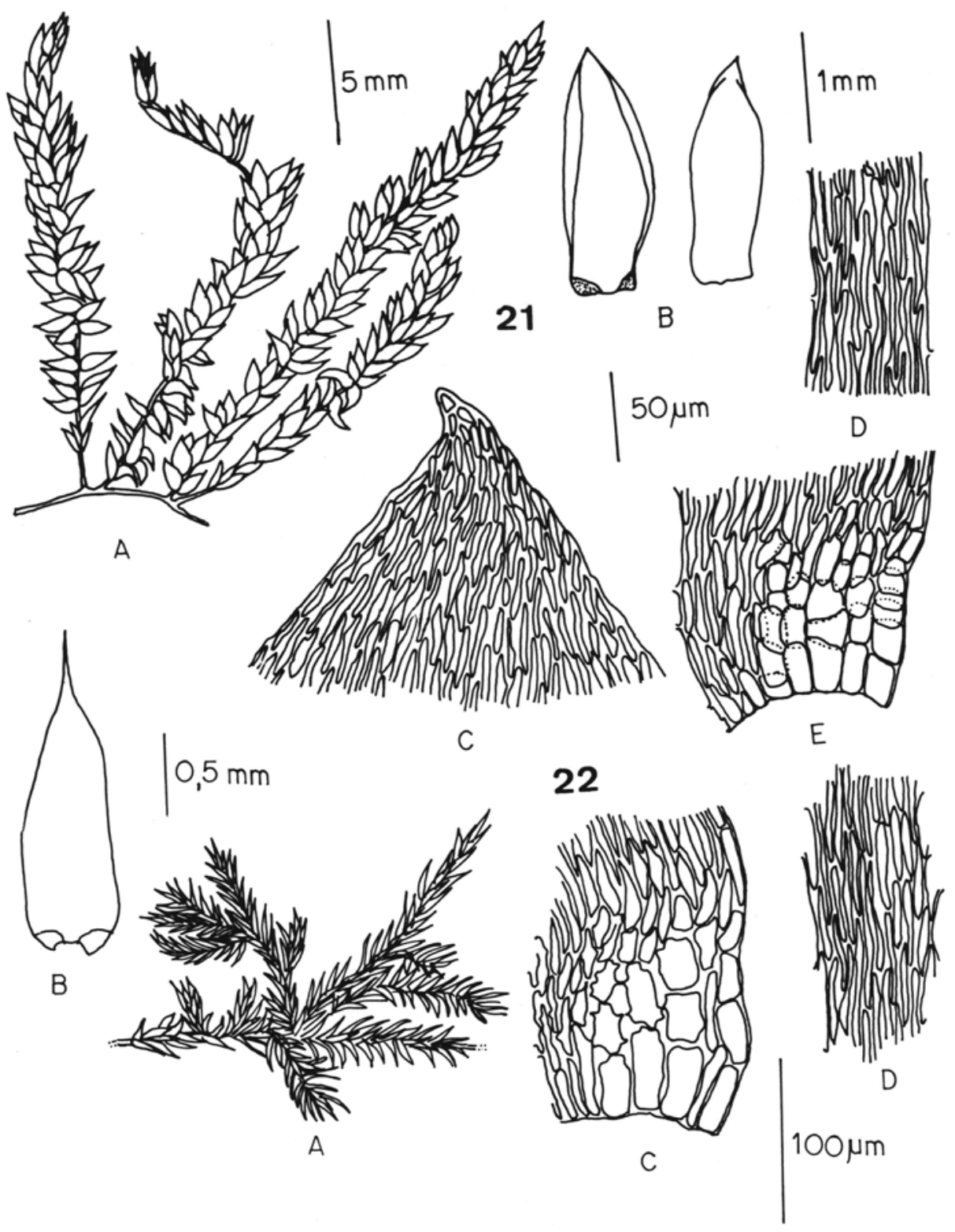

Figura 21. Sematophy llum campicola A) Gametófito; B) Filídios; C) Células apicais do filídio; D) Células medianas do filídio; E) Células basais do filídio. Figura 22. Sematophyllum subsimplex A) Gametófito; B) Filídio; C) Células basais do filídio; D) Células medianas do filídio. 
Sematophyllum subsimplex (Hedw.) Mitt., J. Linn. Soc, Bot. 12:494.1869. (fig. 22 AD).

Basiônimo: Hypnum subsimplex Hedw., Spec. Musc. 270.1801.

Localidade-tipo: Indias Ocidentais.

Descrição: Bartram 1949.

Material examinado - Brasil, Estado do Rio de Janeiro, Município de Nova Friburgo, Pico da Caledônea. Sobre tronco de Myrtaceae na mata sombria a mais ou menos 1,5m do solo, alt. 2018 m.s.m., col. D. P. Costa 644 et al., 4-V-1988 (RB 277988); ibidem. Sobre pedra muito úmida, protegido pela vegetação herbácea, alt. 2018 m.s.m., col. D. P. Costa 665 et al., 4-V-1988 (RB 284187).

Comentários - Esta espécie pode ser reconhecida por apresentar filídio oblongo, estreito e acuminado, com células alares diferenciadas e células da lâmina alongadas e lisas.

Ocorre nos Estados de Amazonas, Pará, Maranhão, Goiás, Mato Grosso, Minas Gerais, Rio de Janeiro, São Paulo, Paraná, Santa Catarina, Rio Grande do Sul (Yano 1981, 1989).

Hedwigiaceae

Hedwigidium integrifolium (P. Beauv.) Dix. in C. Jens, Skand. Bladmfl. 369.1939. (fig. $23 \mathrm{~A}-\mathrm{F}$ )

Basiônimo: Hedwigia integrifolia P. Beauv., Prodr. 60.1805.

Localidade-tipo: não localizada.

Descrição: Sehnem 1976.

Material examinado - Brasil, Estado do Rio de Janeiro, Município de Nova Friburgo, Pico da Caledônea. Na pedra, no alto do pico, alt. 2200 m.s.m., col. D. P. Costa 70, 31VIII-1984 (RB 249101); ibidem. Sobre o solo rochoso, heliófila, junto com Eriocaulaceae, alt. 2000 m.s.m., col. D. P. Costa 642 et al., 4-V-1988 (RB 284186).

Comentários - Esta espécie pode ser reconhecida por apresentar gametófitos amareloamarronzados acima e marrom-escuro abaixo; filídios imbricados, largos, ovadolanceolados, curto-acuminados ou apiculados, margem revoluta no ápice; células papilosas, curtas, estreitas ou sinuosas; cápsula imersa.

Ocorre nos Estados de Minas Gerais, Paraná, Santa Catarina (Yano 1981) e está sendo citada pela primeira vez para o Estado do Rio de Janeiro.

Rhacocarpus inermis (C. Müll.) Lindb., in Broth. Act. Soc. Sci. Fenn. 19(5):22.1891. (fig. 24 A-F)

Basiônimo: não localizado.

Localidade-tipo: não localizada.

Descrição: Sehnem 1976. 

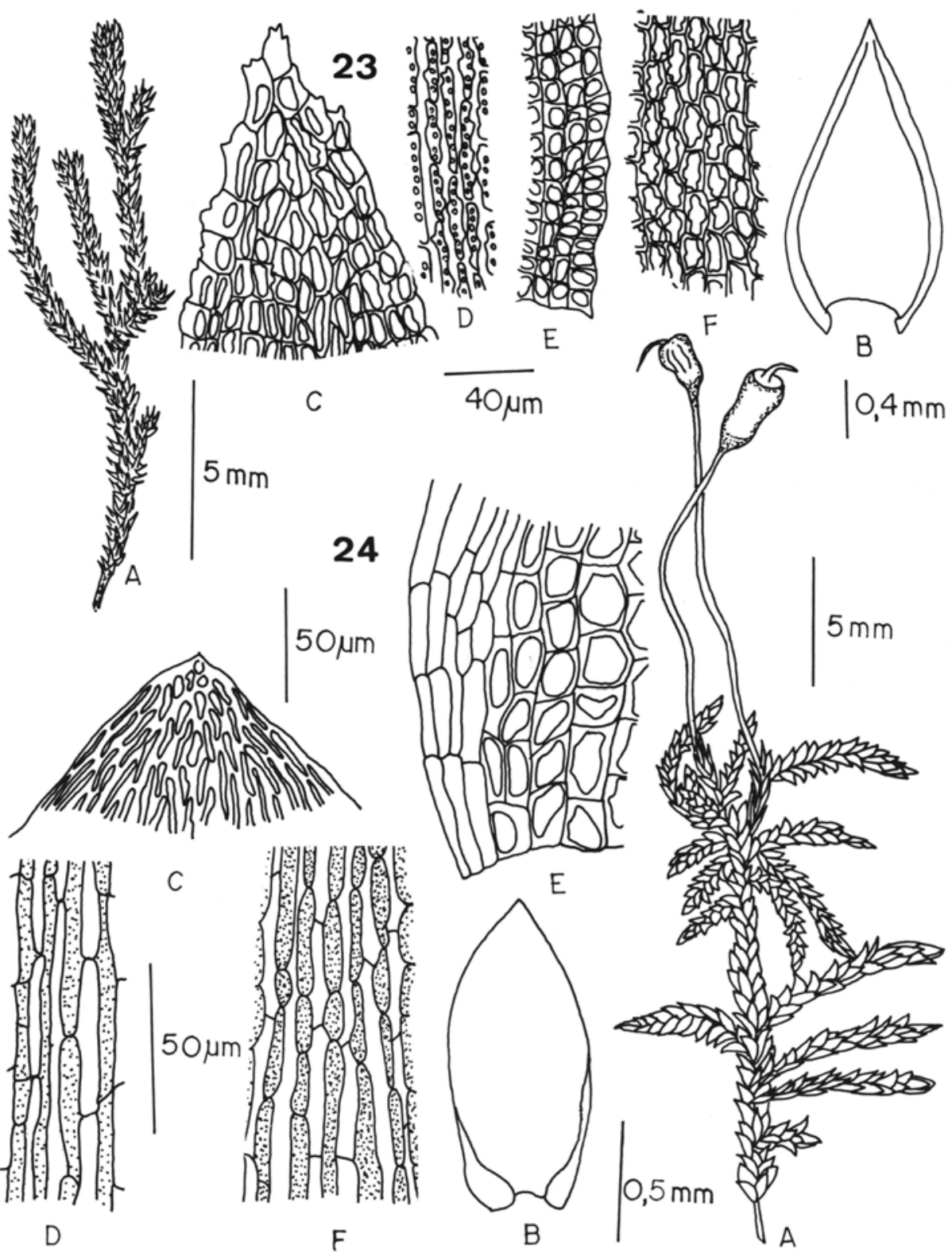

Figura 23. Hedwigidium integrifolium A) Gametófito; B) Filídios; C) Células apicais do filídio; D-E) Células basais do filídio; F) Células medianas do filídio. Figura 24. Rhacocarpus inermis A) Gametófito; B) Filídio; C) Células apicais do filídio; D) Células medianas do filídio; E) Células angulares basais do filídio: F) Células internas basais do filídio. 
Material examinado - Brasil, Estado do Rio de Janeiro, Município de Nova Friburgo, Pico da Caledônea. Sobre pedra no cume do pico, alt. 2020 m.s.m., col. D. P. Costa 64 (RB 230511); ibidem. Rupícola, local muito úmido na trilha no alto do pico, alt. 2020 m.s.m., aparecendo em grande quantidade a partir de 1800 m.s.m., col. D. P. Costa 233 et L. C. Giordano, 2-VI-1987 (RB 259597); ibidem. Sobre paredão rochoso muito úmido, próximo à mata, alt. 2000 m.s.m., col. D. P. Costa 656 et al., 4-V-1988 (RB 272941).

Comentários - Esta espécie pode ser reconhecida por apresentar filídios imbricados, sem costa, base larga, ápice agudo; células alares com paredes espessas, retangulares, de coloração amarronzada, sendo as basais estreitas, densamente micropapilosas.

Ocorre nos Estados de Minas Gerais, Rio de Janeiro, Santa Catarina (Yano 1981).

\section{Meteoriaceae}

Lindigia aciculata (Tayl.) Hampe, Bot. Zeit. 27:868.1969. (fig. 25 A-E).

Basiônimo: Leskea aciculata Tayl., London J. Bot. 6:339.1847.

Localidade-tipo: Nova-Granada.

Descrição: Bartram 1949.

Material examinado - Brasil, Estado do Rio de Janeiro, Município de Nova Friburgo, estrada para as torres de televisão, Rio Caledônea, Reserva da EMASA. Em árvore, misturado com Porotrichum substriatum (Hampe) Mitt. e Mittenothamnium reptans (Hedw.) Card., col. G. L. Ferreira 182 et al., 11-VIII-1987 (RB 265398).

Comentários - Esta espécie pode ser reconhecida por apresentar filídios ovadolanceolados com base larga e cordada; ápice acuminado, serreado; costa terminando acima do meio do filídio; células lineares, não diferenciadas nos ângulos; seta áspera, ligeiramente curva.

Ocorre nos Estados do Paraná, Rio Grande do Sul (Yano 1981, 1989) e está sendo citada pela primeira vez para o Estado do Rio de Janeiro.

Papillaria nigrescens (Hedw.) Jaeg., Ber. S. Gall. Naturw. Ges. 1875-76:265.1877 (ad. 2:169) (fig. 26 A-E)

Basiônimo: Hypnum nigrescens Hedw., Spec. Musc. 250 t. 65 f. 1-4. 1801.

Localidade-tipo: Jamaica.

Descrição: Bartram 1949.

Material examinado - Brasil, Estado do Rio de Janeiro, Município de Nova Friburgo, Rio Caledônea, Pico da Caledônea. Pendente do tronco de um arbusto no riacho no caminho para o pico, muito úmido e sombrio, alt. 1600 m.s.m., col. D. P. Costa 890 et al., 30-III-1989 (RB 288355). 


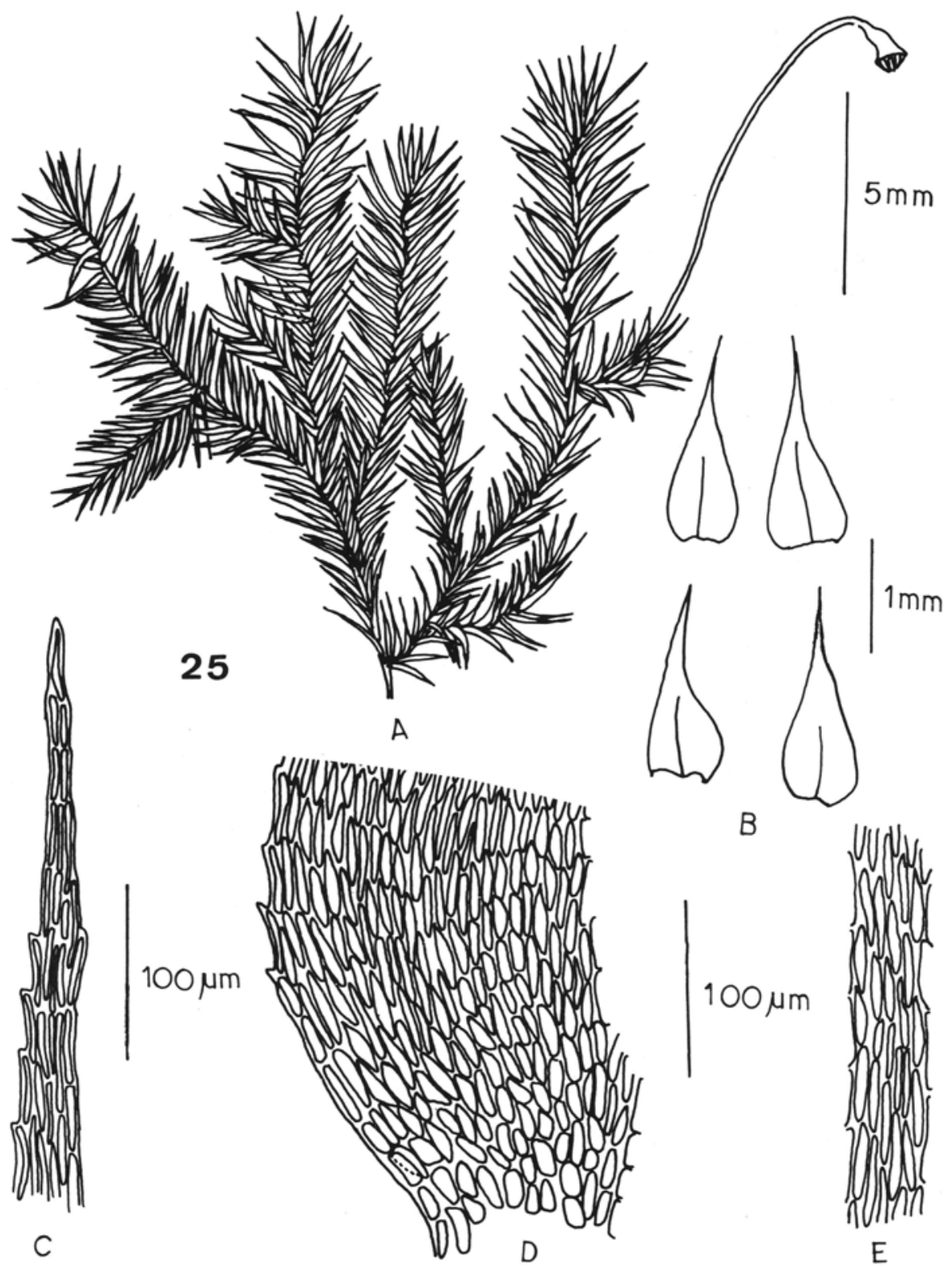

Figura 25. Lindigia aciculata A) Gametófito; B) Filídios; C) Células apicais do filídio; D) Células basais do filídio: E) Célula medianas do filídio. 


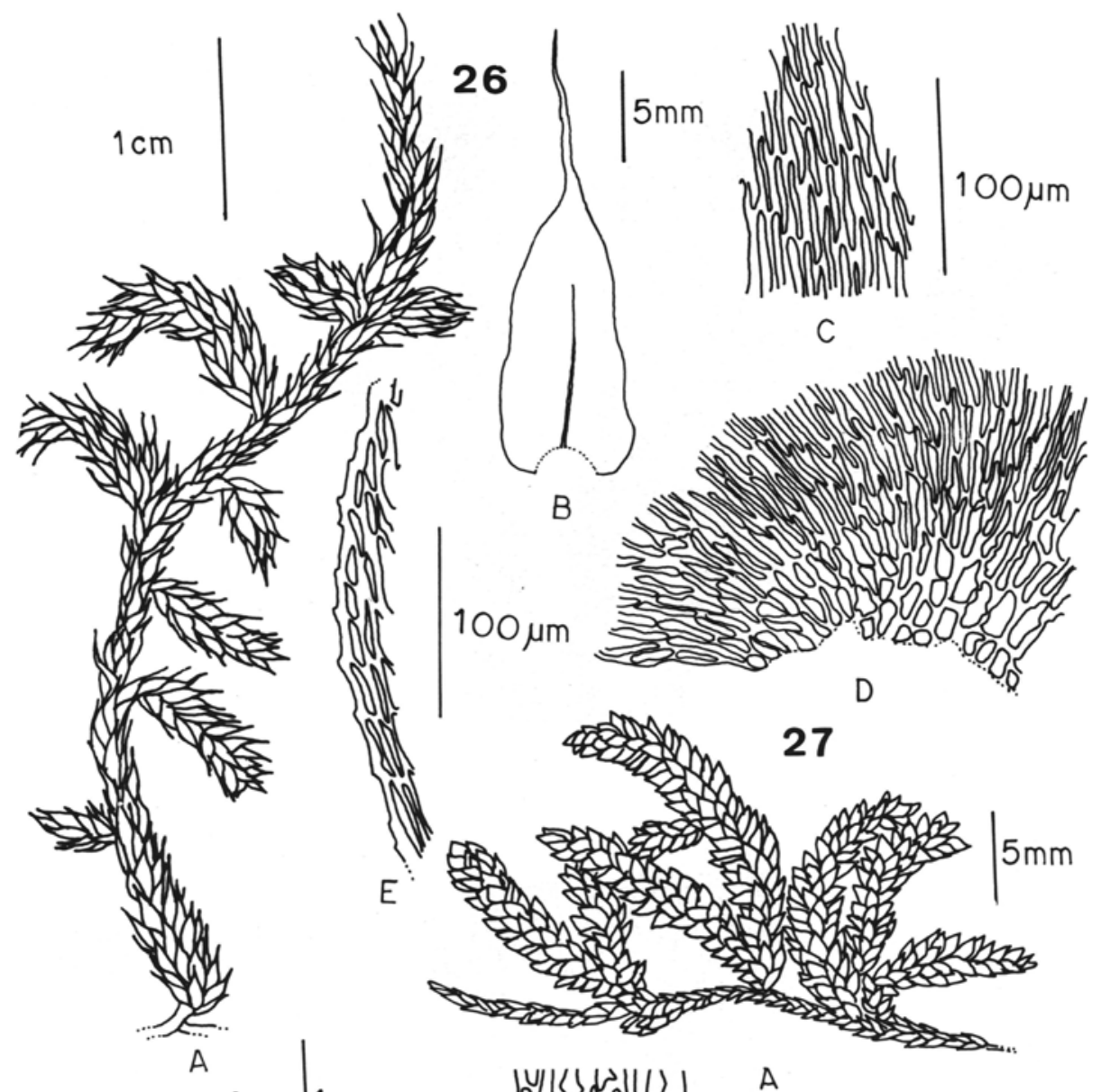

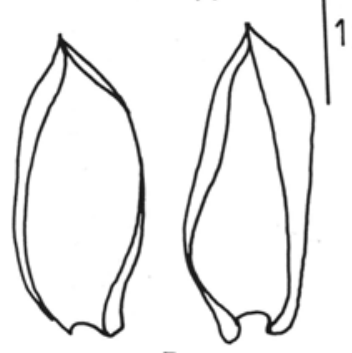

B

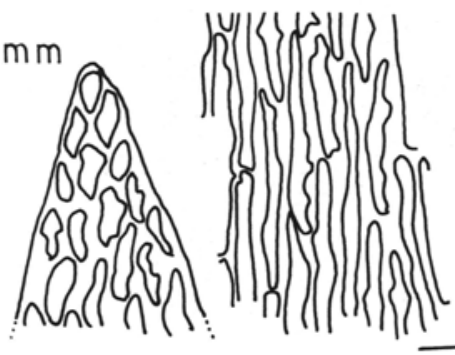

C
A

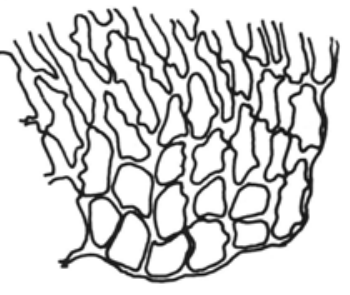

D $50 \mu \mathrm{m}$
$\mathrm{E}$

Figura 26. Papillaria nigrescens A) Gametófito; B) Filidio; C) Células medianas do filídio; D) (élulas basais do filídio; E) Margem do filídio. Figura 27 Pilotrichella flexilis A) Gametófito; B) Filídios; C) Células apicais do filídio: D) Células medianas do filídio; E) Células basais do filídio. 
Comentários - Esta espécie pode ser reconhecida por apresentar gametófitos verdes ou amarelados no ápice e marrons ou pretos na base; filídios ovados com base cordada, acuminados, ligeiramente plicados; margens onduladas, serreadas na base; costa terminando acima do meio do filídio; células lineares ou ovais, papilosas.

Ocorre nos Estados de Minas Gerais, Rio de Janeiro, São Paulo, Paraná, Santa Catarina, Rio Grande do Sul (Yano 1981, 1989).

Pilotrichella flexilis (Hedw.) Aongstr., K. Svensk. Vet. Ak. Handl. 33(11):34.1876. (fig. 27 A-E).

Basiônimo: Leskea flexilis Hedw., Spec. Musc. 234.1801.

Localidade-tipo: Jamaica et insulae australes.

Descrição: Bartram 1949.

Material examinado - Brasil, Estado do Rio de Janeiro, Município de Nova Friburgo, Pico da Caledônea. Na mata nebular, no tronco de árvore, alt. 2200 m.s.m., col. D. P. Costa 63b, 31-VIII-1984 (RB 230540); ibidem. Estrada para torres de televisão, Rio Caledônea, Reserva da EMASA. Em árvore, pendente, col. G. L. Ferreira 177 et al., 11-VIII-1987 (RB 263466); ibidem. Sobre pedra entremeado com línquem cinzento, alt. 1440 a 1600 m.s.m., col. A. M. S. F. Vaz 100, 8-VI-1977 (RB 271635).

Comentários - Esta espécie pode ser reconhecida por apresentar gametófitos com ápices verdes-claros, amarronzados na base; filídios oblongo-ovados com base estreitada e auriculada, ápice curto-apiculado; margem inflexa no ápice; células lineares, sinuosas, sendo as angulares diferenciadas, pequenas e arrendondadas.

Ocorre nos Estados de Pernambuco, Minas Gerais, Rio de Janeiro, São Paulo, Paraná, Santa Catarina, Rio Grande do Sul (Yano 1981, 1989).

\section{Neckeraceae}

Porothamnium leucocaulon (C. Müll.) Fleisch., in Broth. Naturl. Pflanzenfam. ed. 2, 11:200.1925. (fig. 28 A-D).

Basiônimo: Neckera leucocaulon C. Müll., Bull. Herb. Boissier 6:113.1898.

Localidade-tipo: Chile.

Descrição: Sehnem 1980.

Material examinado - Brasil, Estado do Rio de Janeiro, Município de Nova Friburgo, Pico da Caledônea. Em pedra, na beira do rio, col. D. P. Costa 80, 8-IX-1984 (RB 230541).

Comentários - Esta espécie pode ser reconhecida por apresentar gametófitos robustos, caulídio primário prostrado e secundário ereto, estipitado, dendróide; ramos dísticos; filídios oblongos, acuminados, serreados no ápice; costa simples alcançando acima do meio do filídio; células basais lineares sendo as apicais oblongas. 


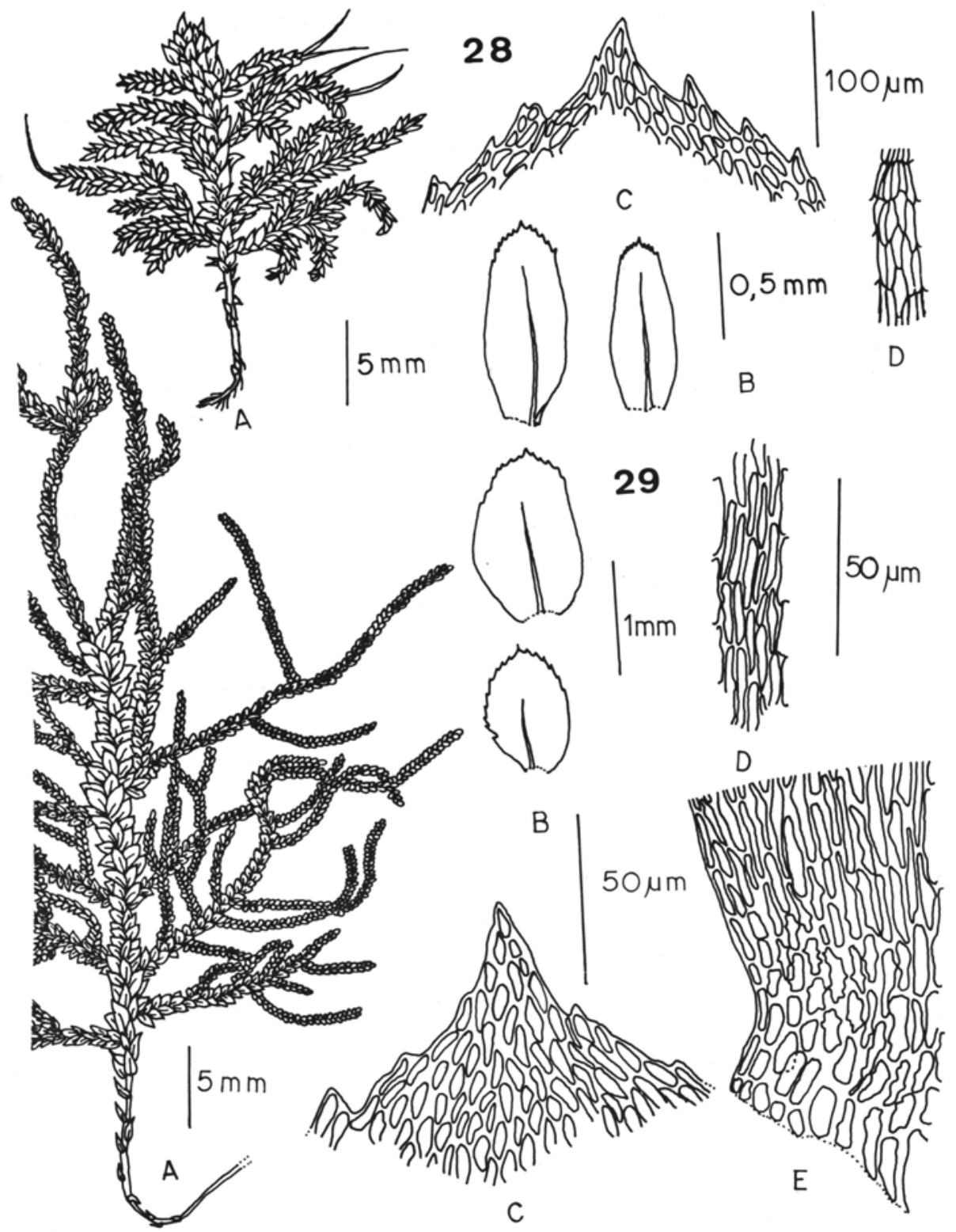

Figura 28. Porothamnium leucocaulon A) Gametófito; B) Filídios; C) Ápice do filídio; D) Células medianas do filídio. Figura 29 Porotrichum korthalsianum A) Gametótifo; B) Filídios do caulídio e do ramo; C) Células apicais do filídio; D) Células medianas do filídio; E) Células basais do filídio. 
Ocorre nos Estados do Rio de Janeiro, São Paulo, Paraná, Santa Catarina, Rio Grande do Sul (Yano 1981, 1989).

Porotrichum korthalsianum (Dozy \& Molk.) Mitt., J. Linn. Soc. Bot. 12:463.1869. (fig. 29 A-E).

Basiônimo: Neckera korthalsianum Dozy \& Molk., Prodr. Fl. Bryol. Surinam. 24.1854 .

Localidade-tipo: Venezuela.

Descrição: Florschütz-de Waard 1986.

Material examinado - Brasil, Estado do Rio de janeiro, Município de Nova Friburgo, Pico da Caledônea. Sobre raiz de Fuchsia sp. num grotão rochoso, alt. 2018 m.s.m., col. D. P. Costa 646, 4-V-1988.

Comentários - Esta espécie pode ser reconhecida por apresentar gametófitos com caulídio primário rastejante e secundário ereto, estipitado, com ramificação pinada ou bipinada, geralmente flageliformes; filídios da estipe triangulares, agudos, com margem serreada no ápice; filídios dos ramos complanados, oval-oblongos, com ápice obtuso, apiculado, curto-acuminado, margem serreada no ápice; costa forte, alcançando 1/2 ou 3/4 do filídio; células do ápice oval-romboidais, medianas oblongo-lineares e basais formando um grupo distinto de células redondo-quadráticas.

Ocorre no Estado do Rio de Janeiro (Yano 1981).

Porotrichum longirostre (Hook.) Mitt., J. Linn. Soc. Bot. 12:461.1869. 9 fig. 30 A-E). Basiônimo: Neckera longirostre Hook., Musc. Exot. tab. 1.1818.

Localidade-tipo: Anduim regiones temperatae.

Descrição: Bartram 1949.

Material examinado - Brasil, Estado do Rio de Janeiro, Município de Nova Friburgo, Pico da Caledônea. Sobre tronco em decomposição no chão da mata sombria e úmida, alt. 2018 m.s.m., col. D. P. Costa 654 et al., 4-V-1988 (RB 284184).

Comentários - Esta espécie pode ser reconhecida por apresentar gametófitos robustos, com ramificação bipinada, base estipitada, ramos atenuados; filídios da estipe pequenos, filídios da fronde complanados, oblongo-ovados, curto-acuminados, serreados; costa subpercurrente; células oval-romboidais.

Ocorre nos Estados de Minas Gerais, Rio de Janeiro, São Paulo, Santa Catarina (Yano 1981, 1989).

Porotrichum plicatulum Mitt., J. Linn. Soc. Bot. 12:461.1869. (fig. 31 A-F).

Localidade-tipo: Trinidad, Arima.

Descrição: Florschütz-de Waard 1986. 


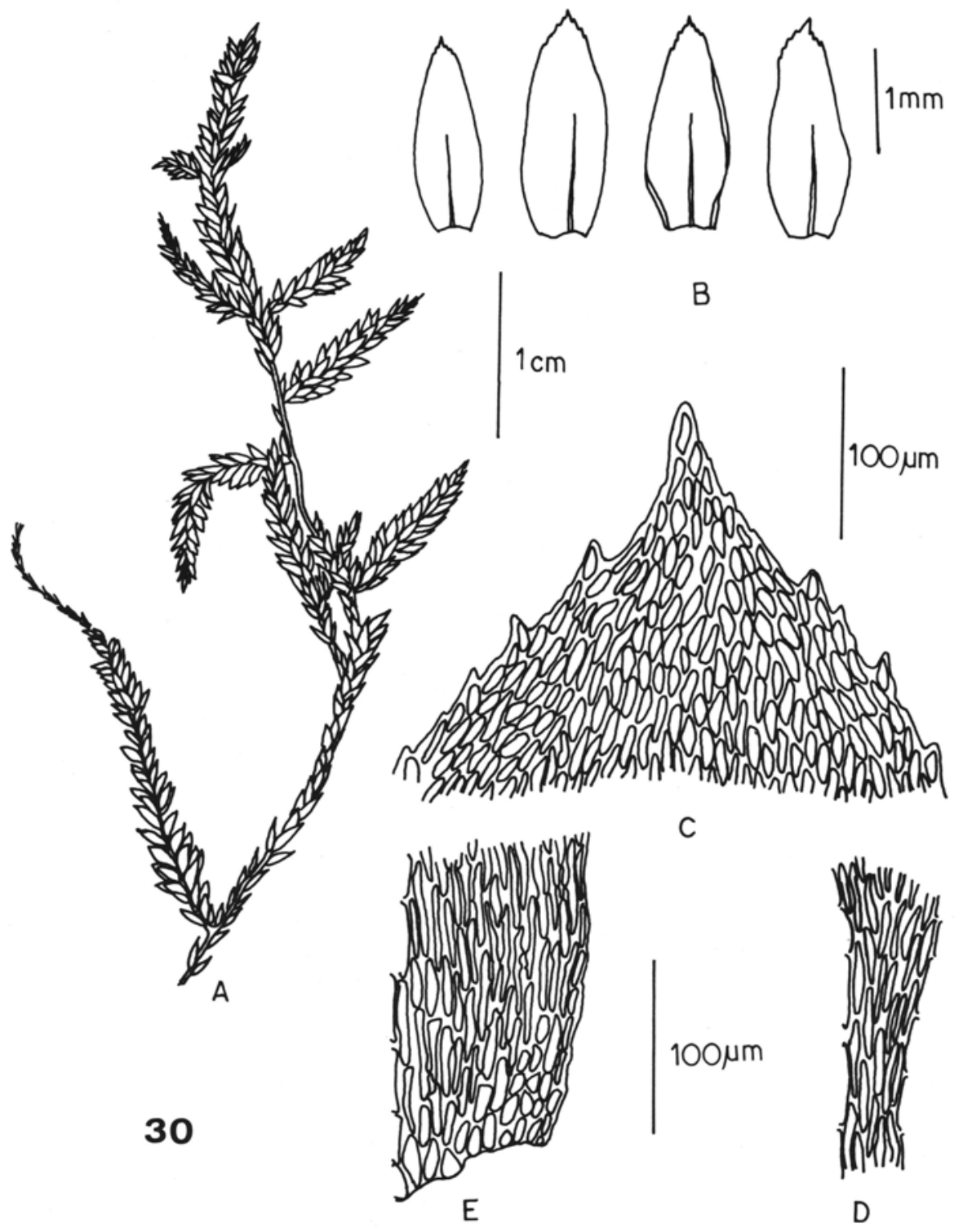

Figura 30. Porotrichum longirostre A) Gametófito; B) Filídios; C) Células apicais do filídio; D) Células medianas do filídio; E) Células basais do filídio. 
Material examinado - Brasil, Estado do Rio de Janeiro, Município de Nova Friburgo, Pico da Caledônea. Sobre ramo de Myrtaceae na mata sombria e úmida, alt. 2018 m.s.m., col. D. P. Costa 645 et al., 4-V-1988 (RB 272956); ibidem. Estrada para torres de televisão, Rio Caledônea, Reserva da EMASA. Em árvore, misturado com Mittenothamnium sp., col. G. L. Ferreira 182 et al., 11-VIII-1987 (RB 265398).

Comentários - Esta espécie pode ser reconhecida por apresentar gametófitos com caulídio primário rastejante e secundário ereto, estipitado, irregularmente pinado ou bipinado, às vezes, flageliforme; filídios da estipe triangular-ovados, agudos ou acuminados; costa acima do meio do filídio; filídios dos ramos ovado-lanceolados, agudos até curto-acuminados; margem serreada na base; células alongado-romboidais; papila apical pequena.

Ocorre nos Estados de Roraima, Rio de Janeiro, São Paulo, Rio Grande do Sul (Yano 1981, 1989).

Phyllogoniaceae

Phyllogonium viride Brid., Bryol. Univ. 2:673.1827. (fig. 32 A-E).

Localidade-tipo: Brasil.

Descrição: Yano \& Mello 1989.

Material examinado - Brasil, Estado do Rio de Janeiro, Município de Nova Friburgo, Pico da Caledônea. Pendente do tronco de uma Myrtaceae, alt. 2018 m.s.m., col. D. P. Costa 641 et al., 4-V-1988 (RB 272947).

Comentários - Esta espécie pode ser encontrada por apresentar filídios dísticos, com ápice fracamente até fortemente recurvado, estreitos com a forma de um arco ou quilha; cápsula imersa.

Ocorre nos Estados de Pernambuco, Bahia, Minas Gerais, Rio de Janeiro, São Paulo, Paraná, Santa Catarina, Rio Grande do Sul (Yano 1981, 1989).

Das quatro espécies e uma variedade de Phyllogonium Brid. anteriormente citadas para o Brasil, $P$. caldense C. Müll., P. fulgens viride (Brid.) Ren. et Card., $P$. immersum Mitt. e P. riograndense C. Müll ex Broth., 3 espécies e 1 variedade foram sinonimizadas por Lin (1983), sendo que o gênero, atualmente está representado no Brasil por 2 espécies, $P$. fulgens e $P$. viride.

\section{Callicostaceae}

Cyclodictyon albicans (Hedw.) Kuntze, Rev. Gen. Pl. 2:835.1891 (fig. 33 A-E).

Basiônimo: Hypnum albicans Hedw., Spec. Musc. 251.1801.

Localidade-tipo: Jamaica.

Descrição: Bartram 1949. 


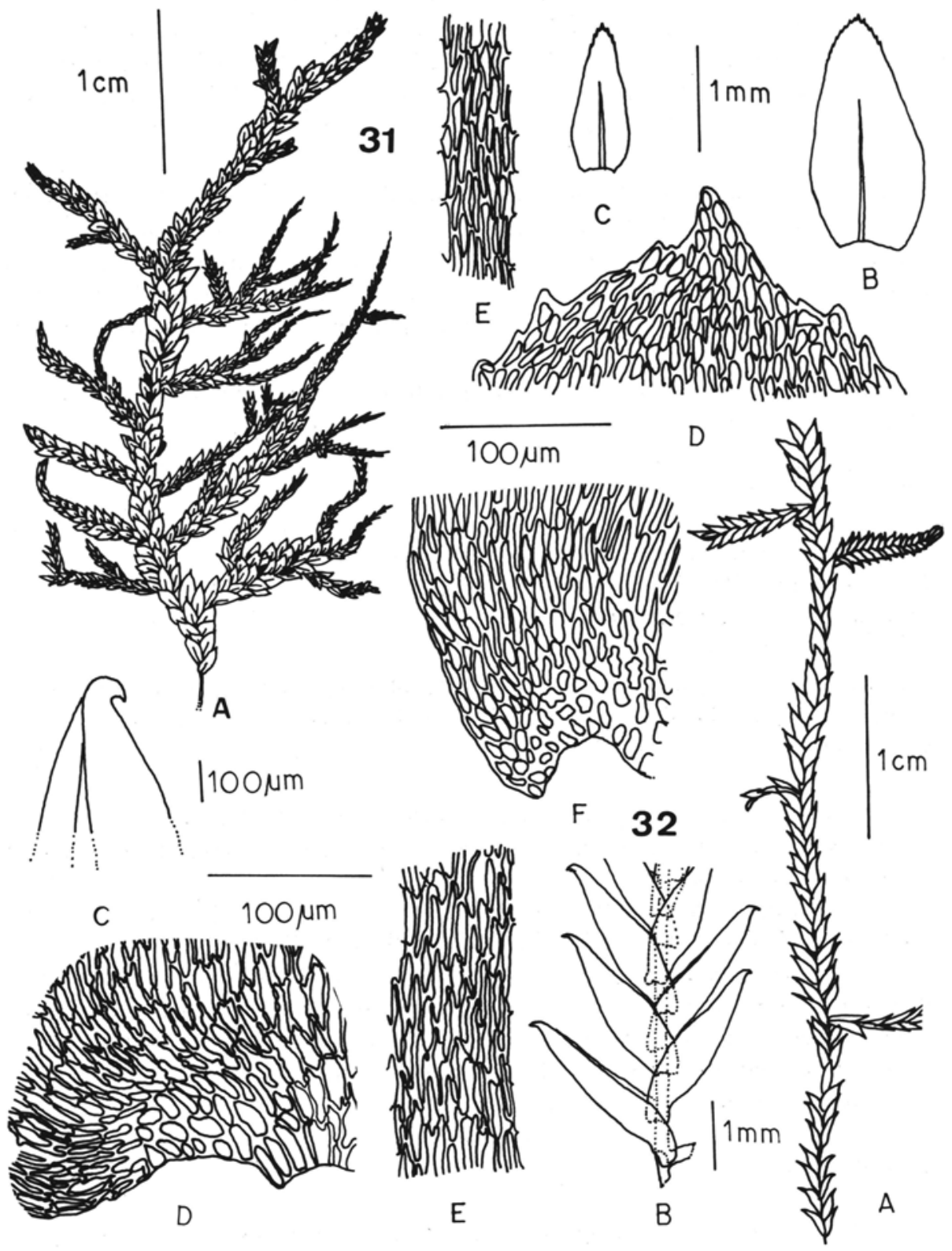

Figura 31. Porotrichum plicatulum A) Gametófito; B) Filídios do caulídio; C) Filídios do ramo; D) Células apicais do filídio; E) Células medianas do filídio; F) Células basais do filídio. Figura 32. Phyllogonium viride A) Gametófito; B) Detalhe dos filídios no caulídio; C) Ápice do filídio; D) Células medianas do filídio; E) Células basais do filídio. 
Material examinado - Brasil, Estado do Rio de Janeiro, Município de Nova Friburgo, Pico da Caledônea. Sobre paredão rochoso do lado da nascente, muito úmido e sombrio, alt. 2018 m.s.m., col. D. P. Costa 661 et al., 4-V-1988 (RB 277991).

Comentários - Esta espécie pode ser reconhecida por apresentar filídios laterais longos, oblongo-ovados, curto-acuminados, bordeado com 1-3 fileiras de células alongadas e estreitas, serreados no ápice, costa dupla percurrente; células redondohexagonais, com paredes finas.

Ocorre nos Estados de Minas Gerais, Rio de Janeiro, Paraná, Rio Grande do Sul (Yano 1981, 1989).

\section{Pottiaceae}

\section{Barbula sp.}

Material examinado - Brasil, Estado do Rio de Janeiro, Município de Nova Friburgo, Pico da Caledônea. Sobre o solo humoso protegido pela vegetação herbácea, úmido, alt. 2018 m.s.m., col. D. P. Costa 670 et al., 4-V-1988 (RB 284176).

Comentários - É um gênero pioneiro, habitando solos pertubados, paredes ou rochas. Pode ser caracterizado por apresentar peristômio com dentes longos e retorcidos e membrana basal pouco desenvolvida.

\section{Dicranaceae}

Bryohumbertia filifolia (Hornsch.) J.-P. Frahm, Cryptogamie, Bryol. Lichénol. 3:366.1981 (fig. 35 A-H).

Basiônimo: Dicranum filifolium Hornsch., Fl. Brasil. 1:12.1840.

Localidade-tipo: Brasil, Nova Friburgo.

Descrição: Frahm 1979.

Material examinado - Brasil, Estado do Rio de Janeiro, Município de Nova Friburgo, Pico da Caledônea. No solo humoso da mata de altitude, muito úmido e protegido pela vegetação herbácea, alt. 2018 m.s.m., misturado com Symphyogyna sp. e Microlepidozia verrucosa (Steph.) Steph., col. D. P. Costa 658 et al., 4-V-1988 (RB 272946).

Comentários - Esta espécie pode ser reconhecida por apresentar os ápices dos filídios estreitos e hialinos.

Ocorre nos estados do Amazonas, Bahia, Minas Gerais, Rio de Janeiro, São Paulo, Paraná, Santa Catarina, Rio Grande do Sul (Yano 1981, 1989). 


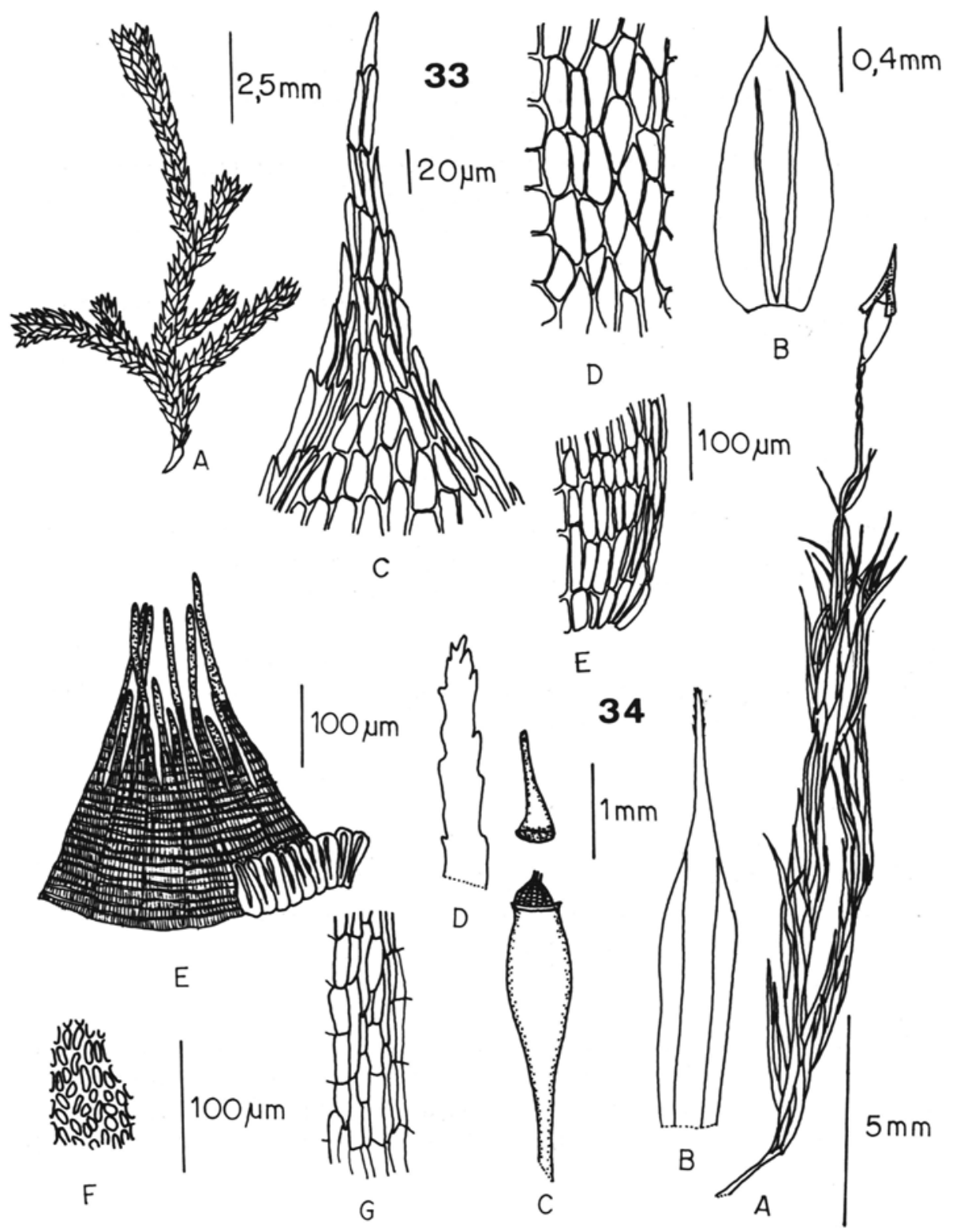

Figura 33. Cyclodictyon albicans A) Gametófito; B) Filídios; C) Ápice do filídio; D) Células medianas do filídio; E) Células basais do filídio. Figura 34. Campylopus beyrichianus A) Gametófitos; B) Filídio; C) Cápsula e opérculo; D) Ápice do filídio; E) Dentes do peristômio e ânulus; F) Células da lâmina na região mediana; G) Células da lâmina na base. 
Campylopus beyrichianus Dub.. Mem. Soc. Phys. Hist. Nat. Geneve 20:359.1870. (fig. 34 A-G).

Localidade-tipo: Brasil, Rio de Janeiro.

Descrição: Frahm (1979).

Material examinado - Brasil, Estado do Rio de Janeiro, Município de Nova Friburgo, Pico da Caledônea. Formando no solo um tapete, col. D. P. Costa 65, 31-VIII-1984 (RB 249098).

Comentários - Esta espécie pode ser reconhecida por apresentar filídios eretos, estreito-lanceolados, denteados no ápice; costa larga, excurrente com 1/3-1/4 da largura do filídio na base, com lamelas tricelulares na superfície dorsal e estereídios dorsais e ventrais; células basais externas quadráticas até curto-romboidais. 1989).

Ocorre nos estados do Rio de Janeiro, São Paulo, Rio Grande do Sul (Yano

Campylopus gemmatus (C. Müll.) Par., Ind. Bryol. 82.1900. (fig. 36 A-F).

Basiônimo: Dicranum gemmatum C. Müll., Bull. Herb. Boissier 6:34.1898.

Localidade-tipo: Brasil, Rio de Janeiro, Serra de Itatiaia.

Descrição: Frahm 1979.

Material examinado - Brasil, Estado do Rio de Janeiro, Município de Nova Friburgo, Pico da Caledônea. Sobre ramo de arbusto na mata perenifólia, umbrófila, alt. 2020 m.s.m., col. D. P. Costa 225 et al., 2-VI-1987 (RB 265401); ibidem. Sobre bambu (Schuskeia sp.) em decomposição na mata de altitude, alt. 2018 m.s.m., idem 667 et al., 4-V-1988 (RB 272937).

Comentários - Esta espécie pode ser reconhecida por apresentar gametófitos pequenos, desenvolvendo em pequenos tufos frouxos. Caulídios simples ou ramificados, ramos fasciculados, estrelados, filídios ereto-imbricados, com base longamente lanceolada, subulados, atenuados, com ápice hialino; costa larga ocupando 3/4 da lâmina na base, seção transversal com grandes hialocistos ventrais; células da lâmina retangulares e alongadas. Propagação vegetativa por massas de propágulos produzidos nas axilas dos filídios.

Ocorre no Estado do Rio de Janeiro, sendo citada para a Serra dos Orgãos e Serra de Itatiaia (Yano 1981, 1989).

Campylopus reflexisetus (C. Müll.) Broth. in Engler e Prantl., Naturl. Pflanzenfam. 1(3):332.1901. (fig. 37 A-E).

Basiônimo: Dicranum reflexisetum C. Müll., Linnaea 38:586.1874.

Localidade-tipo: Colômbia.

Descrição: Frahm 1991. 


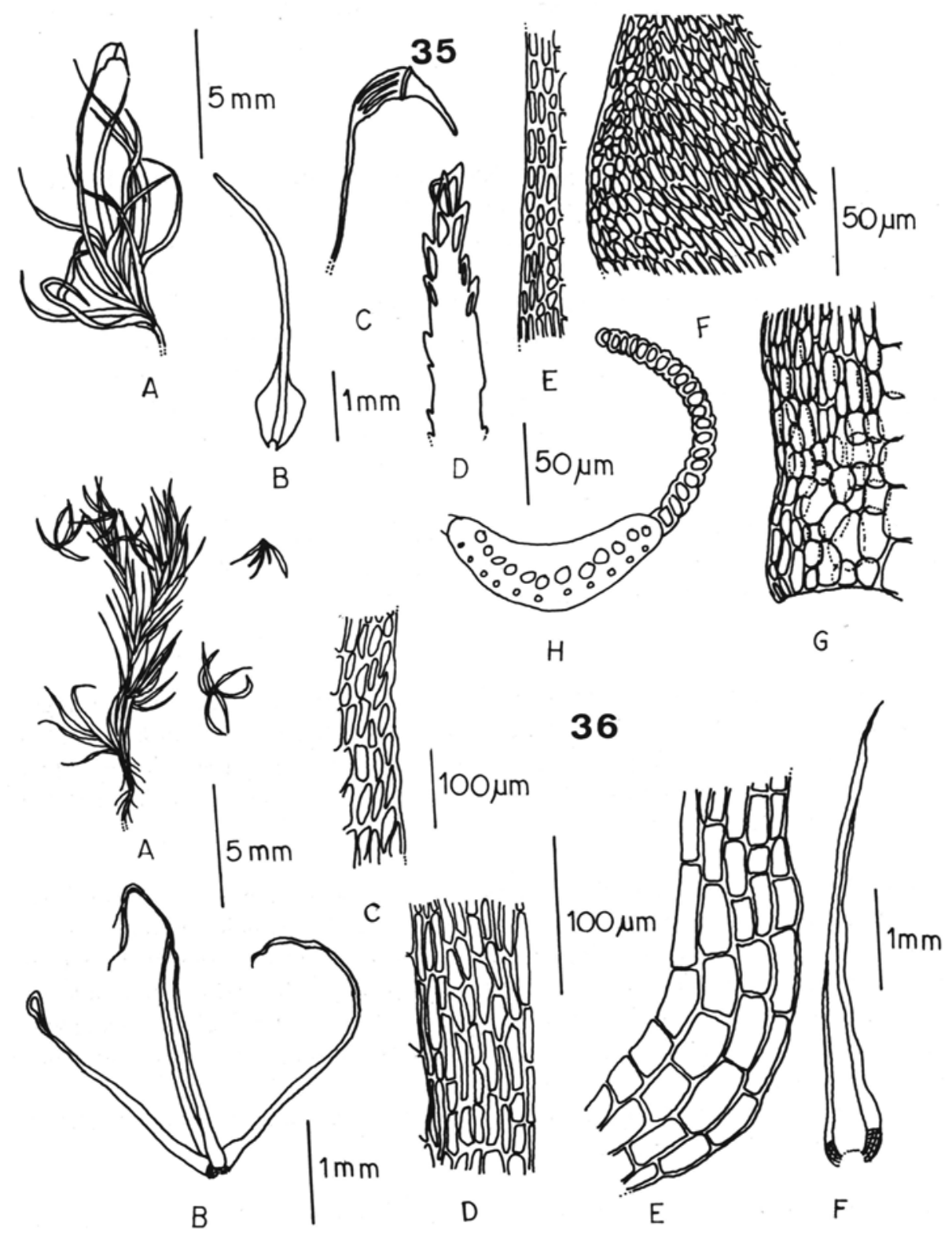

Figura 35. (umpỵlopus filifolius A) Gametófito; B) Filídio; C) Cápsulas; D) Células do ápice do filídio; E) Células da margem do filídio; F) Células medianas do filídio; G) Células da base; H) Corte transversal do filídio. Figura 36. Campylopus gemmatus A) Gametófito; B) Propágulos; C) Células da lâmina no ápice do filídio; D) Células da margem do filídio; E) Células angulares do filídio; F) Filídio. 
Material examinado - Brasil, Estado do Rio de Janeiro, Município de Nova Friburgo, Pico da Caledônea. Sobre paredão rochoso ao lado da nascente, muito úmido e sombrio, alt. 2018 m.s.m., col. D. P. Costa 660 et al., 4-V-1988 (RB 284185).

Comentários - Esta espécie pode ser reconhecida por apresentar filídio ereto, expandido, estreitamente lanceolado, terminando numa longa súbula; costa larga com 1/2 da largura do filídio na base, em seção transversal com uma camada de células retangulares, as da margem mais longas, estreitas e hialinas.

Ocorre no Estado do Rio de Janeiro, em Itatiaia (Yano 1989).

Campylopus richardii Brid., Mant. Musc. 73.1819. (fig. 38 A-G).

Localidade-tipo: Guadelupe.

Descrição: Frahm 1979.

Material examinado - Brasil, Estado do Rio de Janeiro, Município de Nova Friburgo, caminho para o Pico da Caledônea. Sobre barranco exposto à beira da estrada, coberto pelo extrato herbáceo, junto com Polytrichum sp.., alt. 2000 m.s.m. col. D. P. Costa 224 et al., 2-VI-1987 (RB 259589).

Comentários - Esta espécie pode ser reconhecida por apresentar filídios do caulídios com ápice freqüentemente hialinos e denticulados; costa com 1/2-1/3 da largura do filídio na base, em seção transversal com estereídios dorsais e ventrais.

Ocorre nos Estados de Minas Gerais, Rio de Janeiro, Paraná (Yano 1981, 1989).

\section{Dicranella $s p$.}

Material examinado - Brasil, Estado do Rio de Janeiro, Município de Nova Friburgo, Pico da Caledônea. Barranco exposto perto do rio, col. D. P. Costa 68, 31-VIII-1984 (RB 263889).

Comentários - Este gênero apresenta distribuição cosmopolita. Como o material se encontra estéril foi impossível identificá-lo a nível específico.

Holomitrium crispulum Mart., Icon. Pl. Crypt. 35:18.1828. (fig. 39 A-F).

Localidade-tipo: Brasil, Minas Gerais.

Descrição: Martius 1828-1834.

Material examinado - Brasil, Estado do Rio de Janeiro, Município de Nova Friburgo, Pico da Caledônea. Na mata nebular, no tronco de árvore viva, col. D. P. Costa 63a, 31-VIII-1984 (RB 249095).

Comentários - Esta espécie pode ser reconhecida por apresentar filídios recurvados, 


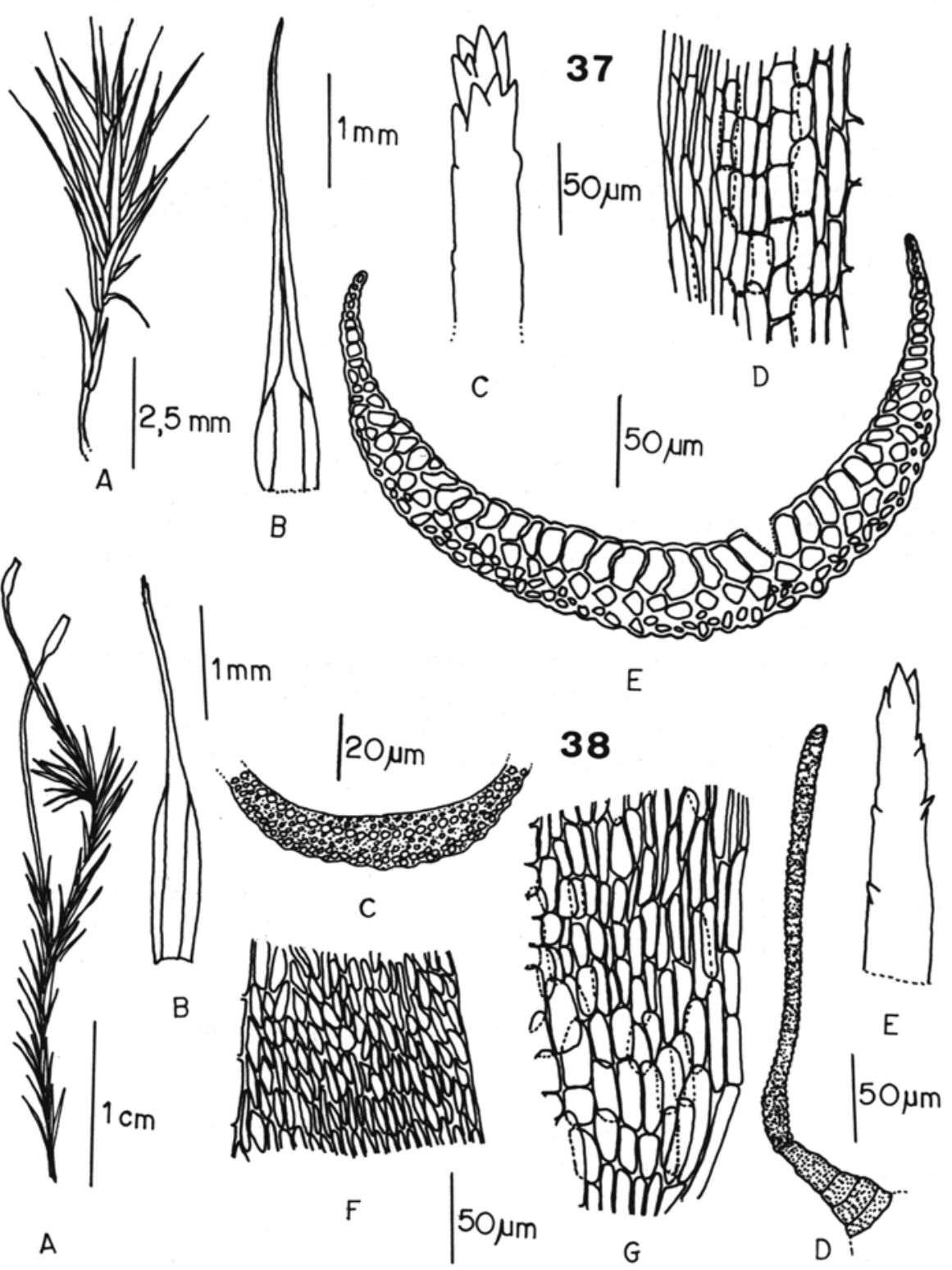

Figura 37. Campylopus reflexissetus A) Gametófito; B) Filídio; C) Ápice do filídio; D) Células da lâmina na base; E) Corte transversal do filídio. Figura 38. Campylopus richardii A) Gametófitos; B) Filídio; C) Corte transversal do filídio; D) Dentes do peristômio; E) Ápice do filídio; F) Células superiores da lâmina; G) Células basais da lâmina. 
com base alargada envolvendo o caulídio, lanceolados, subulados, agudamente serreados e com costa excurrente. Filídios periqueciais muito longos, lanceolados, subulados e estreitamente invaginantes.

Ocorre nos Estados de Pernambuco, Minas Gerais, Rio de Janeiro, São Paulo (Yano 1981, 1989).

Leucoloma serrulatum Brid., Bryol. Univ. 2:752.1827. (fig. 40 A-F).

Localidade-tipo: Espanha.

Descrição: Bartram 1949.

Material examinado - Brasil, Estado do Rio de Janeiro, Município de Nova Friburgo, Rio Caledônea, Reserva da EMASA. Em galho de árvore, col. G. L. Ferreira 170et al., 11-VIII-1987 (RB 2777987).

Comentários - Esta espécie pode ser reconhecida por apresentar filídios falcados e flexuosos quando secos e eretos quando úmidos; linear-lanceolados, estreitados para o ápice que é agudo; margem serreada; costa percurrente, serreada; células inferiores próximas a costa, pequenas, ovais até oblongas e papilosas, próximas a margem, longas, estreitas, lisas e hialinas, dispostas em várias fileiras que diminuem em direção do ápice, no ângulo basal formam aurículas retangulares e são de coloração amarronzadas.

Ocorre nos Estados de Pernambuco, Minas Gerais, Rio de Janeiro, São Paulo (Yano 1981, 1989).

Pilopogon guadeloupensis (Brid.) J-P. Frahm, Fl. Neotr. Mon. 54. 238p. 1991. (fig. 41 A-G).

Basiônimo: Dicranum guadeloupensis Brid., Spec. Musc. 1:213.1806.

Localidade-tipo: Guadeloupe.

Descrição: Frahm 1991.

Material examinado - Brasil, Estado do Rio de Janeiro, Município de Nova Friburgo, Pico da Caledônea. Crescendo sobre rochas com fina camada de terra bem úmida, alt. 900 m.s.m., col. J. F. Baumgratz 310 et al., 14/15-I-1985 (RB 260146).

Comentários - Esta espécie pode ser reconhecida por apresentar caulídio delicado, tomentoso; filídios estreitamente lanceolados, ápice subtulosos e denticulado, costa lisa, excurrente, ocupando $1 / 2$ da lâmina na base; células alares não diferenciadas, as basais retangulares e as apicais alongadas com paredes ligeiramente espessas. Seta ereta ou ligeiramente flexuosa, rugosa; cápsula cilídrica, ânulus ausente; peristômio com dentes cilíndricos, não divididos, filiformes, papilosos.

Ocorre nos Estados do Paraná, Santa Catarina, Rio Grande do Sul (Yano 1981) e está sendo citada pela primeira vez para o Estado do Rio de Janeiro. 


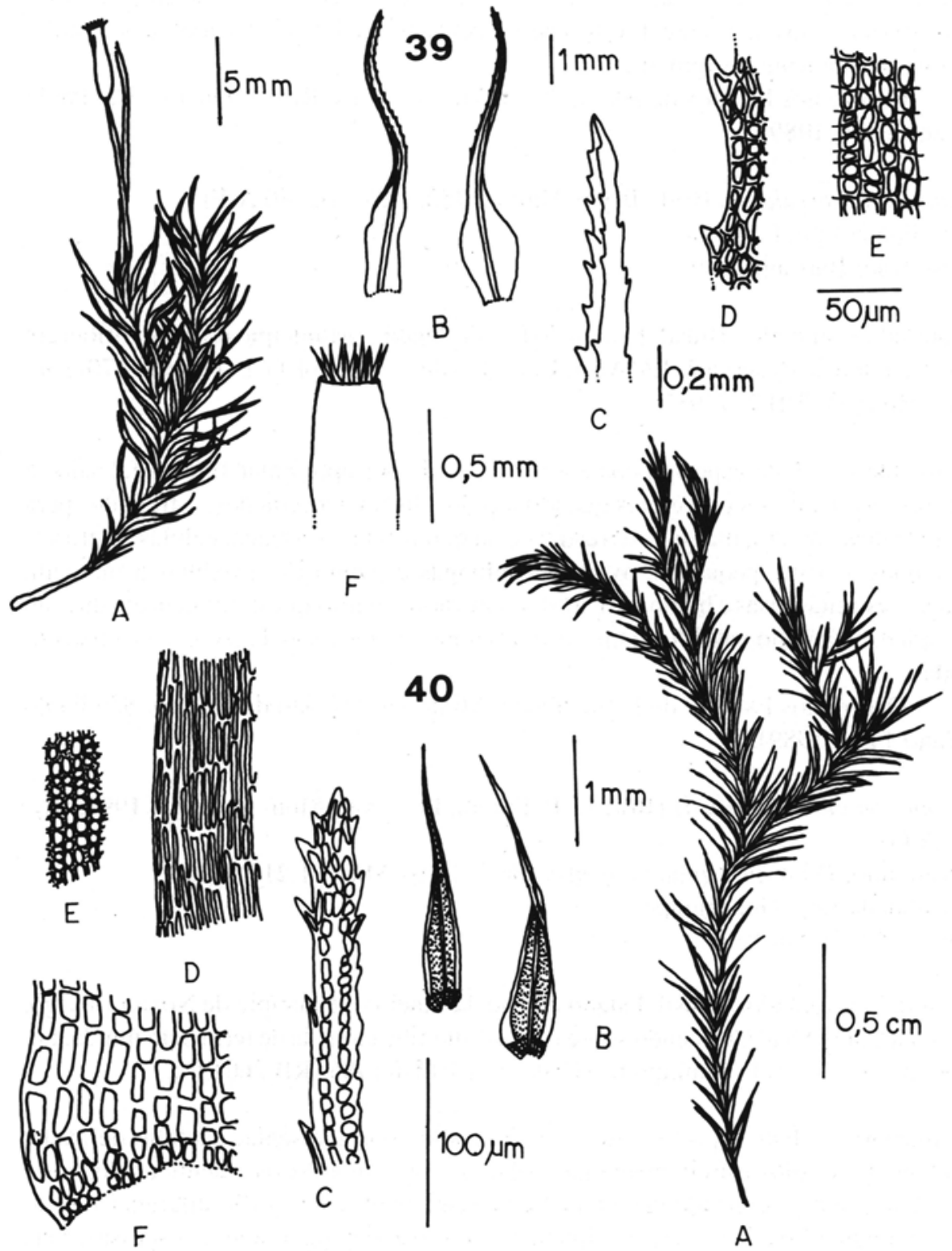

Figura 39. Holomitrium crispulum A) Gametófito; B) Filídios; C) Ápice do filídio; D) Margem do filídio; E) Células do filídio; F) Cápsula. Figura 40. Leucoloma serrulatum A) Gametófito; B) Filídios; C) Ápice do filídio; D) Células da margem do filídio; E) Células medianas do filídio; F) Células basais do filídio. 
Leucobryaceae

Leucobryum albicans (Schwaegr.) Lindb., Öfvers. K. Sv. Vet-Akad. Forh. Stockholm. 20:402.1863.

Basiônimo: Dicranum albicans Schwaegr., Supl. Spec. Musc. II. 2(2):122.1827. Localidade-tipo: Brasil, Rio de Janeiro.

Descrição: Costa 1986/1988.

Material examinado - Brasil, Estado do Rio de Janeiro, Município de Nova Friburgo, Morro da Caledônea. Umbrófila, rupícola, verde-claro, estéril, col. G. Martinelli 2533, 8-VI-1977 (RB 193215).

Comentários - Esta espécie pode ser reconhecida por apresentar filídios longos, afilados, com base ovada, ápice inteiro ou denticulado; leucocistos em 4 camadas.

Ocorre nos Estados do Ceará, Pernambuco, Bahia, Minas Gerais, Rio de Janeiro, São Paulo, Paraná, Santa Catarina (Yano 1981, 1989).

Leucobryum clavatum Hampe var.clavatum, Vidensk. Meddl. Dansk. Naturh. Foren., Kjobenhavn, sér. 3,9-10:252.1877.

Localidade-tipo: Brasil, Rio de Janeiro.

Descrição e ilustração: Costa 1986/1988.

Material examinado - Brasil, Estado do Rio de Janeiro, Município de Nova Friburgo, estrada as torres de televisão, Rio Caledônea, reserva da EMASA. Em terra, substrato húmus, col. G. L. Ferreira 174 et al., 11-VIII-1987 (RB 265386).

Ditrichaceae

Ceratodon purpureus (Hedw.) Brid., Bryol. Univ. 1:480.1826. (fug. 42 A-D). Basiônimo: Dicranum purpureum Hedw., Spec. Musc., p. 136, 1801. Localidade-tipo: Europa.

Material examinado - Brasil, Estado do Rio de Janeiro, Município de Nova Friburgo, Pico da Caledônea. Entre pedras da estrada, protegido pela vegetação herbácea, alt. 1830 m.s.m., col. D. P. Costa 232 et al., 2-VI-1987 (RB 259596).

Comentários - Esta espécie pode ser reconhecida por apresentar os filídios com a margem fortemente enrolada ou reflexa próxima do ápice o qual é serreado; células apicais isodiamétricas e lisas enquanto que as células basais são curtamente retangulares.

A espécie foi mencionada para o Brasil por Brotherus (1924) sem indicação precisa do local de coleta. Assim, está sendo citada pela primeira vez para o Estado do Rio de Janeiro. 


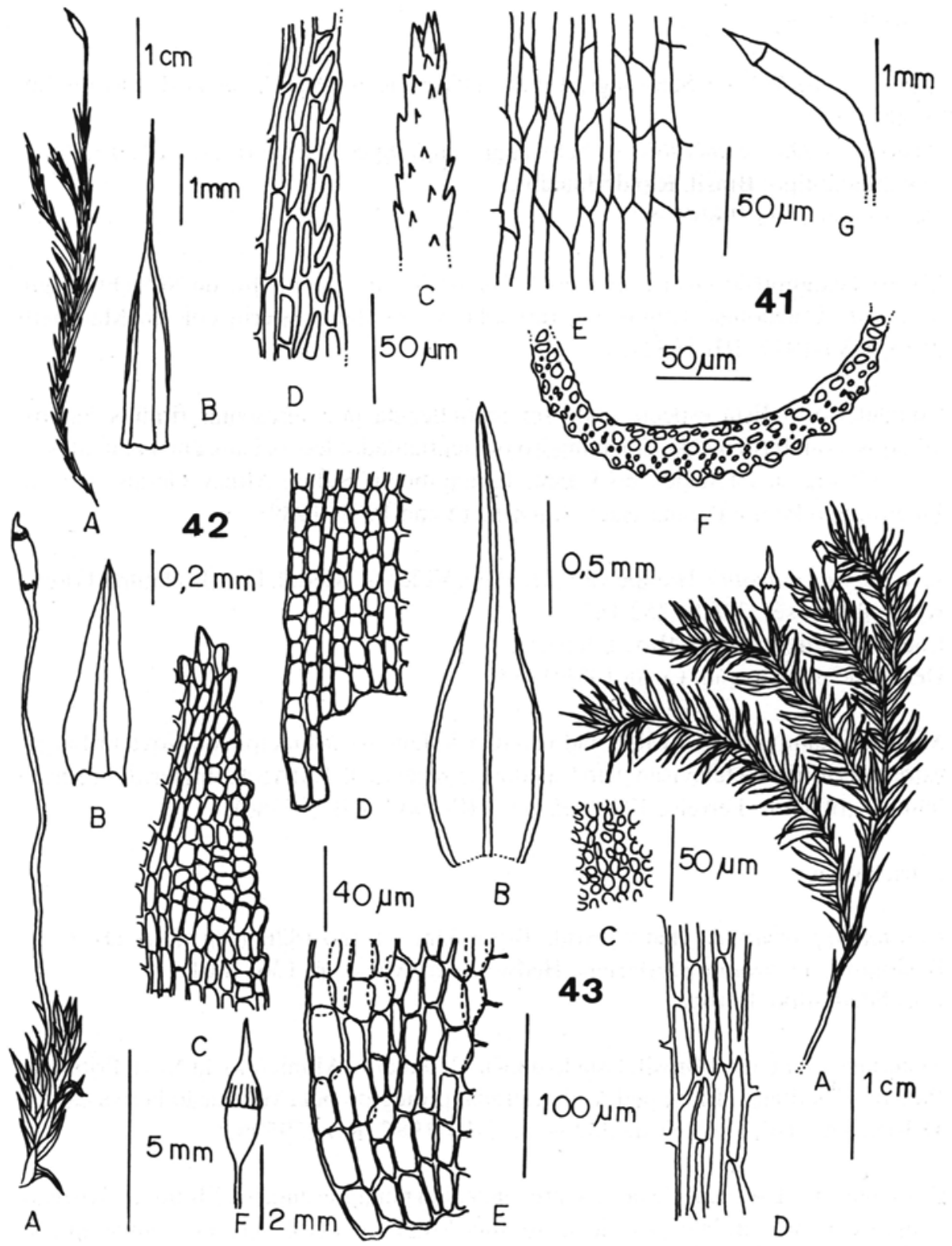

Figura 4I. Pilopogon guadeloupensis A) Gametólito; B) Filidios; C) Ápice do filídio: D) Células apicais do filídio; E) Células basais do filídio; F) Corte transversal do filídio; G) Cápsula. Figura 42. Ceratodon purpureus A) Gametófito; B) Filídio; C) Células do ápice do filídio; D) Células da base do filídio. Figura 43. Ptychomitrium sellowianum A) Gametófito; B) Filídio; C) Células medianas do filídio; D) Células basais internas do filídio; E) Células basais externas do filídio; F) Esporófito. 
Ptychomitriaceae

Ptychomitrium sellowianum (C. Müll.) Jaeg., Ber. S. Gall. Naturw. Ges. 1872-73 (Add. 1:382) (fig. $43 \mathrm{~A}-\mathrm{F}$ ).

Localidade-tipo: Brasil austral oriental, Montevideo.

Descrição: Sehnem 1969.

Material examinado - Brasil, Estado do Rio de Janeiro, Município de Nova Friburgo, estrada para as torres de televisão, Rio Caledônea, Reserva da EMASA. Na pedra do córrego, col. G. L. Ferreira 179 et al., 11-VIII-1987 (RB 263375).

Comentários - Esta espécie pode ser reconhecida por apresentar gametófitos de coloração verde-oliva, amarelados no ápice; filídios enrolados quando secos e patentes quando úmidos, com base larga, recurvados, lanceolados-acuminados, careniformes; peristômio simples, dentes divididos profundamente.

Ocorre nos Estados de Minas Gerais, Rio de Janeiro, Paraná, Santa Catarina, Rio Grande do Sul. (Yano 1981, 1989).

\section{Discussão e conclusões}

No Pico da Caledônea foram coletadas 104 amostras de briófitas sendo identificadas 74 espécies, das quais 53 são de musgos (Bryopsida) e 21 são de hepáticas (Hepaticopsida). Neste trabalho são apresentados somente dados sobre os musgos, o que vem complementar o levantamento da brioflora do Pico da Caledônea.

As espécies encontradas pertencem as seguintes famílias: Bartramiaceae(Philonotis glauscescens); Bryaceae (Anomobryum filiforme, Bryum argenteum, B. billarderi, B.roseolum); Dicranaceae (Bryohumbertia filifolia, Campylopus beryrichianus, C. gemmatus, C. reflexisetus, C. richardii, Dicranella sp., Holomitrium crispulum, Leucoloma serrulatum, Pilopogon guadeloupensis); Ditrichaceae(Ceratodon purpureus); Funariaceae (Funaria hygrometrica); Hedwigiaceae (Hedwigidium integrifolium, Rhacocarpus inermis); Callicostaceae (Cyclodictyon albicans); Hypnaceae (Mittenothamnium heterostachys, M. langsdorfii, M. reptans, ); Leucobryaceae (Leucobryum albicans, L. clavatum); Meteoriaceae(Lindigia aciculata, Papillaria nigrescens, Pilotrichella flexilis); Neckeraceae (Porothamnium leucocaulon, Porotrichum Korthalsianum, P. longirostre, P. plicatulum); Orthotrichaceae (Schlotheimia rugifolia); Phyllogoniaceae (Phyllogonium viride); Plagiomniaceae (Plagiomnium rhychophorum); Polytrichaceae(Atrichum androgynum var. oerstedianum, Pogonatum campylocarpum, Polytrichadelphus magellanicus, Polytrichum commune, P. juniperinum); Pottiaceae (Barbulasp.) Ptychomitriaceae(Ptychomitrium sellowianum); Rhizogoniaceae(Pyrrhobryum spiniforme); Sematophyllaceae(Aptychella proligera, Sematophyllum caespitosum, S. campicola, S. subsimplex); Sphagnaceae (Sphagnum ovatum, $S$. palustre, S. recurvum, S. subsecundum); Stereophyllaceae (Stereophyllum radiculosum); Thuidiaceae(Cyrtohypnum minutulum, Thuidium recognitum var. delicatulum). 
As famílias que se apresentaram em maior número foram: Dicranaceae, com 5 gêneros e 9 espécies e Polytrichaceae, com 4 gêneros e 5 espécies.

Entre as 53 espécies de musgos encontradas no Pico da Caledônea, Anomobryum filiforme (Dicks.) Husn., Ceratodon purpureus (Hedw.) Brid., Cyrtohypnum minutulum (Hedw.) Buck. \& Crum, Hedwigidium integrifolium (P. Beauv.) Dix., Lindigia aciculata (Tayl.) Hampe, Pilopogon guadeloupensis (Brid. J.-P. Frahm e Sematophyllum campicola (Broth.) Broth. estão sendo citadas pela primeira vez para o Estado do Rio de Janeiro, enquanto que Aptychella proligera (Broth.) Herz. e Sphagnum ovatum Schimp. in Warnst. estão sendo citadas pela primeira vez para o Brasil.

Pode-se considerar que no Pico da Caledônea há um número considerável de espécies, devido provavelmente, ao conjunto de fatores locais que propiciam o desenvolvimento de briófitas, como por exemplo, o alto índice pluviométrico e a nebulosidade intensa, que proporcionam uma atmosfera úmida e com pouca luminosidade.

\section{Agradecimentos}

Gostaria de agradecer ao Dr. Dana Griffin III, da Universidade da Flórida, ao Dr. William R. Buck, do Jardim Botânico de Nova York e ao Dr.Jaakko Hyvönen, da Universidade de Helsink, pela identificação de alguns táxons e a Dra. Olga Yano, do Instituto de Botânica de São Paulo, por suas valiosas sugestões e orientação no trabalho.

\section{Referências bibliográficas}

Bartram, E. B. 1928. Costa Rican Mosses Collected by Paul C. Standley in 1924-1926. Contr. Univ. St. Nat. Herb. 26(3):51-114.

Bartram, E. B. 1949. Mosses of Guatemala. Fieldiana Bot. 25:1-442.

Breen, R. S. 1963. Mosses of Florida. Gainesville: Univ. of Florida Press. Book.

Brotherus, V. F. 1909. Andreaeaceae und Bryales. In Engler \& Prantl. (eds.) Die naturlichen Pflanzenfamilien, ed. 1, vol. 1(3):265-268, 177-1246. Leipzig.

Brotherus, V. F. 1924-25. Musci (Laubmoose). In Engler \& Prantl. (eds.) Die naturlichen Pflanzenfamilien, ed. 2, 10:1-478. Leipzig.

Buck, W. R. 1987. Taxonomic and nomenclatural rearrangement in the Hookeriales with notes on West Indian taxa. Brittonia 39(2):210-224.

Buck, W. R. \& Ireland, R. R. 1985 A reclassification of the Plagiotheciaceae. Nova Hedwigia. 41:89-125,

Costa, D. P. 1986/88. Leucobryaceae do Parque Nacional da Tijuca no Estado do Rio de Janeiro (Brasil). Rodriguesia 64/66(40/41):41-48.

Costa, D. P. 1992. Hepáticas do Pico da Caledônea, Município de Nova Friburgo, Rio de Janeiro. Acta bot. bras. 6(1):3-39.

Crum, H. 1976. Mosses of the Great Lakes Forest. Contr. Univ. Mich Herb. 10:1-104.

Crum, H \& Steere, W. C. 1957. The mosses of Porto Rico and the Virgin Island. Sci Surv. P. Rico. 7(4):396-599.

Eddy, A. 1977. Sphagnales of Tropical Asia. Bull. Br. Mus. nat. Hist. (Bot.) 5(7):357-445.

Eddy, A. 1988. A Handbook of Malesian Mosses (Sphagnales to Dicranales). vol. 1. British Museum. $204 \mathrm{p}$. 
Enroth, J. 1989. Bryophyte flora of the Huon Peninsula, Papua New Guinea XXVIII. Neckeraceae (Musci). Acta Bot. Fenn. 137:41-80.

Farias, H. C. 1982 A família Polytrichaceae no Rio Grande do Sul, Brasil. Porto Alegre: Universidade Federal do Rio Grande do Sul. Dissertação de Mestrado

Farias, H. C. 1984. A família Polytrichaceae no Rio Grande do Sul, Brasil. I. Taxonomia. Iheringia, sér. Bot. 32:77-89.

Fife, A. J. 1985. A generic revision of the Funariaceae (Bryophyta: Musci). Part I. J. Hattori Bot. Lab. 58:149-196.

Florschütz, P. A. 1964. The mosses of the Suriname 1.

Florschütz-De Waard, J. 1986. Flora of Suriname Musci. Part II, 6(1):273-361.

Frahm, J.-P. 1974. Zur Unterscheidung und Verbreitung von Campylopus introflexus (Hedw.) Brid. und C. polytrichoides De Not. Revue Bryol. Lichen 40(1):33-44.

Frahm, J.-P. 1975. Taxonomische Notizen zur Gattung Campylopus. Revue Bryol. Lichen. 41(3):32 1-332.

Frahm, J.-P. 1978. Taxonomische Notizen zur Gattung Campylopus. Revue Bryol. Lichen. 29:243-250.

Frahm, J.-P. 1979. Dia Campylopus - Arten Brasiliens. Revue Bryol. Lichen. 45(2):127-178.

Frahm, J.-P. 1991. Dicranaceae: Campylopodioideae, Paraleucobryoideae. Flora Neotropica, 54. New York: New York Botanical Garden.

Gier, L. J. 1980. A preliminary study of the Thuidiaceae (Musci) of Latin America. J. Bryol. 11:253-309.

Griffin, III, D. 1979. Guia preliminar para as briófitas freqüentes em Manaus e adjacências. Acta Amazonica 9(3):1-67.

Grout, A. J. 1903. Mosses with hand-lens and microscope. New York.

Grout, A. J. 1945. A revision on the North American species of Stereoplyyllum and Pilosium, with descriptions of some South American species. Bryologist. 48(2):60-70.

Hyvönen, J. 1986. Bryophyte flora of the Huon Peninsula, Papua New Guinea, XVIII. Polytrichaceae and Buxbaumiaceae (Musci). Acta Bot. Fennica. 133:107-149.

Hyvönen, J. 1989. A synopsis of genus Pogonatum (Polytrichaceae, Musci). Acta Bot. Fennica. 138:1-87.

Ireland, R. R. \& Belloio-Trucco, G. 1987. Illustraded guide to some hornworts, liverworts and mosses of eastern Canada. Syllogeus 62:1-205.

Kabiersch, W. 1938. Studien uber die ostasiatischen Arten einiger Laubmoosfamilien II. (Rhizogoniaceae, Bartramiaceae, Aulacomniaceae, Meeseaceae). Hedwigia 16:71-136.

Koponen, T. 1979. A synopsis of Mniaceae (Bryophyta). 1. South and Central American taxa. J. Hattori Bot. Lab. 46:155-161.

Koponen, T. 1981. A synopsis of Mniaceae (Bryophyta). VI. Southeast Asian taxa. Acta Bot. Fennica 117:1-34

Koponen, T. 1988. The phylogeny and classification of Mniaceae and Rhizogoniaceae (Musci). J. Hattori Bot. Lab. 64:37-46.

Koponen, T. \& Norris, D. H. 1983. Bryophyte flora of the Huon Peninsula, Papua New Guinea. II. Mniaceae (Musci). Ann. Bot. Fennici 20:31-40.

Koponen, T. \& Norris, D. H. 1984. Bryophyte flora of the Huon Peninsula Papua New Guinea. IV. Anomobryum, Bryum, Rhodobryum (Bryaceae, Musci). Ann. Bot. Fennici 21:265-290.

Koponen, T. \& Norris, D. H. 1985. Bryophyte flora of the Huon Peninsula Papua New Guinea. XI. Brachymenium, Epipterygium, Leptobryum, Mielichoferia, Orthodontium and Pohlia (Bryaceae) and Leptostomaceae (Musci). Acta Bot. Fennici. 131:99-127.

Koponen, T. \& Norris, D. H. 1986a. Bryophyte flora of the Huon Peninsula Papua New Guinea. XIV. Rhizogoniaceae. Acta Bot. Fennici. 133:1-24.

Koponen, T. \& Norris, D. H. 1986b. Bryophyte flora of the Huon Peninsula Papua New Guinea. XVIII. Grimmiaceae, Racopilaceae and Hedwigiaceae (Musci). Acta Bot. Fennici. 133:81-106.

Lin, S. -H. 1983. A Taxonomic revision of Phyllogoniaceae (Bryopsida). Part I. J. Taiwan Museum 36(2):37-86.

Lin, S. -H. 1983. A Taxonomic revision of Phyllogoniaceae (Bryopsida). Part II. J. Taiwan Museum 37(2): $1-54$.

Magill, R. E. 1987 Flora of Southern Africa. Part 1 mosses Fascicle 2 Gigaspermaceae-Bartramiaceae. 
Martius, C. F. P. 1828-1834. Icones plantarum cryptogamicarum, quas in itinere annis 1817-1820 per Brasilian instituto collegit et descripsit i-iv + 1-138, fig. 1-76 (Bryophyte, 31-36, fig. 15-20). Monachii.

Matteri, C. M. 1975. Las Hookerliales (Musci) andino-patagonicas. 1. Nova Hegwigia 26:649-724.

Mello, Z. R. \& Yano, O. 1991. Musgos do manguezal do Rio Guaruí, Peruíbe, São Paulo. Revta. brasil. Bot. 14:35-44.

Menzel, M. 1986. The genus Pogonatum P. Beauv. (Musci: Polytrichaceae) in Latin America. Lindbergia 12:43-46.

Mitten, W. 1869. Musci austro-americani. Enumeratio muscorum omnium austroamericanorum hucuscusque cognitorum. J. Linn. Soc. bot. 12:1-659.

Mullen, D. \& Frye, T. C. 1947. Middle and South American species of Oligotrichum. Bryologist. 50(1):6779.

Noguchi, A. 1987. Moss flora of Japan part 1. J. Hattori Bot. Lab. 1-1-242.

Noguchi, A. 1988. Moss flora of Japan part 2. J. Hattori Bot. Lab. 2:243-491.

Norris, D. H. \& Koponen, T. 1985. Bryophyte flora of the Huon Peninsula Papua New Guinea. VII. Trachypodiaceae, Thuidiaceae and Meteoriaceae (Musci). Acta Bot. Fennici. 131:1-52.

Norris, D. H. \& Koponen, T. 1988. Bryophyte flora of the Huon Peninsula Papua New Guinea. XXIV. Andreaeaceae, Archidiaceae, Seligeriaceae and Ditrichaceae (Musci). Acta Bot. Fennici. 25:165-177.

Nyholm, E. 1971. Studies in the genus Atrichun P. Beauv. A short survey of the genus and the species. Lindbergia 1:1-33.

Ochi, H. 1968. A Revision of the family Funariaceae (Musci) in Japan and adjacent regions. Jap. Journ. Bot. 20(1):1-34.

Ochi, H. 1980. A Revision of the Neotropical Bryoideae, Musci (First Part.) J. Fac. Educ. Tottori Univ. 29(2):49-154.

Ochi, H. 1981. A Revision of the Neotropical Bryoideae, Musci (Second Part.) J. Fac. Educ. Tottori Univ. 30:21-55.

Ochi, H. 1982. A Revision of Bryoideae (Musci) in Southern South America. J. Fac. Educ. Tottori Univ. 31:11-47.

Sainsbury, G. O. K. 1955. A Handbook of the New Zealand Mosses. Roy. Soc. New Zealand. 5:1-490.

Saito, K. 1975. A monography of Japanese Pottiacea (Musci). J. Hattori Bot. Lab. 39:373-537.

Schiavone, M. M. 1988a. Notas preliminares sobre Polytricachaceae de Tierra del Fuego I. La morfologia interna del nervio como caracter generico. Lilloa 37(1):9-14.

Schiavone, M. M. 1988b. Notas preliminares sobre Polytrichaceae de Tierra del Fuego II. Caracteres anatomicos del gametofito de Dendroligotrichum y Polytrichadelphus. Lilloa 37(1):91-12.

Schuster, R. M. 1983-84. New Manual of Bryology. Vol. 1 e 2. Hustrado II. gr8vo. Bound.

Sehnem, A. 1969. Musgos sul-brasileiros 1. Pesquisas, ser. bot. 27:1-41.

Sehnem, A. 1970. Musgos sul-brasileiros 2. Pesquisas, ser. bot. 28:1-117.

Sehnem, A. 1972. Musgos sul-brasileiros 3. Pesquisas, ser. bot. 29:1-70.

Sehnem, A. 1976. Musgos sul-brasileiros 4. Pesquisas, ser. bot. 30:1-79.

Sehnem, A. 1978. Musgos sul-brasileiros 5. Pesquisas, ser. bot. 32:1-170.

Sehnem, A. 1979. Musgos sul-brasileiros 6. Pesquisas, ser. bot. 33:1-149.

Sehnem, A. 1980. Musgos sul-brasileiros 7. Pesquisas, ser. bot. .34:1-121

Sloover, J. D. de. 1976. Note de bryologie africaine VII. Pseudephemerum, Bryohumbertia, Eucladium, Streptopogon, Ptychomitrium, Rhachythecium, Antitrichia, Pterogonium, Lindigia, Distichophyllum, Bull. Jard. Bot. Nat. Belg. 46:427:447.

Sloover, J. D. de. 1977. Note de bryologie africaine IX. Andreaea, Racomitrium, Gymnostomiella, Thuidium Bull. Jard. Bot. Belg. 47:155:181.

Sloover, J. D. de. 1983. Note de bryologie africaine XII. Porotrichum et Porothamnium. Bull. Jard. Bot. Belg. 53:97-152.

Smith, G. L. 1971. Conspectus of the genera of Polytrichacea. Mem. New York Bot. Gard. 21(3):1-83.

Tixier, P. 1977. Clastobryoidees et taxa apparentées. Rev. Bryol. Lichenol. 43(4):397-464. 
Touw, A. 1975/76. A taxonomic revision of Thuidium, Pelekium and Rauiella (Musci: Thudiaceae) in Africa South of the Sahara. Lindbergia 3:135-195.

Vitt, D. H. 1984. Classification of the Bryopsida. In R. M. Schuster (ed.), New Manual of Bryology 2:696795.

Welch, W. H. 1966. The Hookeriaceae of Mexico. Bryologist 69(1):1-68.

Welch, W. H. 1976. Hookeriaceae. North America Flora 2(9):1-133.

Williams, R. S. 1913. Dicranaceae e Leucobryaceae. North America Flora 15(2):159-166.

Yano, O. 1975. Leucobryaceae (musci) do Estado de São Paulo. São Paulo: Escola Paulista de Medicina. Dissertação de Mestrado.

Yano, O. 1981. A checklist of Brazilian mosses. J. Hattori Bot. Lab. 50:279-456.

Yano, O. 1984a. Briófitas. In Fidalgo, O. e Bononi, V. L. R., (coord.) Técnicas de coleta e herborização de material botânico. São Paulo. Instituto de Botânica (manual n. 4).

Yano, O. 1984b. Contribuição ao inventário dos Musci brasileiros: Racopilaceae (Bryopsida, Isobryales). Revta. bras. Bot. 7:57-63.

Yano, O. 1985. Octoblepharum (Leucobryaceae) do alto Rio Negro, Amazonas (Brasil). Acta Amazonica supl. 15(1-2):55-62.

Yano, O. 1986. Contribuição ao inventário dos Musci brasileiros: 5 Rhizogoniaceae (Bryosida). Rickia 13:49-60.

Yano, O. 1989. An additional checklist of Brazilian bryophytes. J. Hattori Bot. Lab. 66:371-434.

Yano, O \& Mello, Z. R. 1989. Estudos de briófitas do Brasil: 6 Phyllogoniaceae (Bryopsida). Acta bot. bras. 3(2):119-129 supl.

Yano, O; Pirani, J. R. \& Santos, D. P. 1985. O gênero Sphagnun (Bryopsida) nas regiões sul e sudeste do Brasil. Revta brasil. Bot. 8:55-80.

Zander, R. H. 1972. Revision of the Genus Leptodontium (Musci) in the World. Bryologist 75(3):213-280. 